\title{
A synthesis of cloud condensation nuclei counter (CCNC) measurements within the EUCAARI network
}

M. Paramonov ${ }^{1, \text { a }}$, V.-M. Kerminen ${ }^{1}$, M. Gysel ${ }^{2}$, P. P. Aalto ${ }^{1}$, M. O. Andreae ${ }^{3}$, E. Asmi ${ }^{4}$, U. Baltensperger ${ }^{2}$,

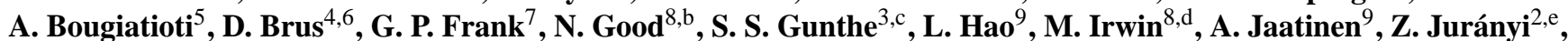
S. M. King ${ }^{10, \text { f }}$, A. Kortelainen ${ }^{9}$, A. Kristensson ${ }^{7}$, H. Lihavainen ${ }^{4}$, M. Kulmala ${ }^{1}$, U. Lohmann ${ }^{11}$, S. T. Martin ${ }^{10}$, G. McFiggans ${ }^{8}$, N. Mihalopoulos ${ }^{5}$, A. Nenes ${ }^{12,13,14}$, C. D. O’Dowd ${ }^{15}$, J. Ovadnevaite ${ }^{15}$, T. Petäjä ${ }^{1}$, U. Pöschl ${ }^{3}$, G. C. Roberts $^{16,17}$, D. Rose $^{3, g}$, B. Svenningsson ${ }^{7}$, E. Swietlicki ${ }^{7}$, E. Weingartner ${ }^{2, \mathrm{e}}$, J. Whitehead ${ }^{8}$, A. Wiedensohler ${ }^{18}$, C. Wittbom ${ }^{7}$, and B. Sierau ${ }^{11}$

${ }^{1}$ Department of Physics, University of Helsinki, P.O. Box 64, 00014 Helsinki, Finland

${ }^{2}$ Laboratory of Atmospheric Chemistry, Paul Scherrer Institute, 5232 Villigen PSI, Switzerland

${ }^{3}$ Biogeochemistry and Multiphase Chemistry Departments, Max Planck Institute for Chemistry, Mainz, Germany

${ }^{4}$ Finnish Meteorological Institute, Erik Palménin aukio 1, P.O. Box 503, 00101 Helsinki, Finland

${ }^{5}$ Environmental Chemical Processes Laboratory, University of Crete, Heraklion, Greece

${ }^{6}$ Laboratory of Aerosols Chemistry and Physics, Institute of Chemical Process Fundamentals, Academy of Sciences of the Czech Republic, Rozvojová 135, 16502 Prague 6, Czech Republic

${ }^{7}$ Division of Nuclear Physics, Department of Physics, Lund University, P.O. Box 118, 22100 Lund, Sweden

${ }^{8}$ Centre for Atmospheric Science, SEAES, The University of Manchester, Oxford Road, Manchester M13 9PL, UK

${ }^{9}$ Department of Applied Physics, University of Eastern Finland, 70210 Kuopio, Finland

${ }^{10}$ School of Engineering and Applied Sciences and Department of Earth and Planetary Sciences, Harvard University, Cambridge, MA 02138, USA

${ }^{11}$ Institute for Atmospheric and Climate Science, ETH Zurich, Zurich, Switzerland

${ }^{12}$ School of Earth and Atmospheric Sciences, Georgia Institute of Technology, Atlanta, GA 30332, USA

${ }^{13}$ School of Chemical and Biomolecular Engineering, Georgia Institute of Technology, Atlanta, GA 30332, USA

${ }^{14}$ Institute of Chemical Engineering Sciences (ICE-HT), FORTH, Patras, Greece

${ }^{15}$ School of Physics and Centre for Climate and Air Pollution Studies, Ryan Institute, National University of Ireland Galway, University Road, Galway, Ireland

${ }^{16}$ Centre National de Recherches Météorologiques, Toulouse, France

${ }^{17}$ Scripps Institution of Oceanography, University of California San Diego, La Jolla, CA 92093, USA

${ }^{18}$ Leibniz Institute for Tropospheric Research, Leipzig, Germany

${ }^{a}$ now at: Institute for Atmospheric and Climate Science, ETH Zurich, Zurich, Switzerland

${ }^{b}$ now at: Department of Mechanical Engineering, Colorado State University, Fort Collins, CO, USA

${ }^{c}$ now at: Department of Civil Engineering, Indian Institute of Technology Madras, Chennai, India

${ }^{d}$ now at: Cambustion Ltd., Cambridge, UK

${ }^{e}$ now at: Institute of Aerosol and Sensor Technology, University of Applied Sciences Northwestern Switzerland, Windisch, Switzerland

f now at: Haldor Topsøe A/S, Copenhagen, Denmark

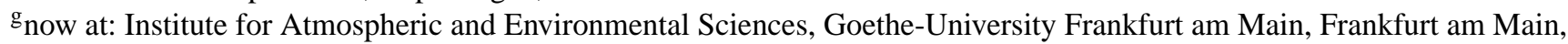
Germany

Correspondence to: M. Paramonov (mikhail.paramonov@helsinki.fi), V.-M. Kerminen (veli-matti.kerminen@ helsinki.fi), M. Gysel (martin.gysel@psi.ch) and B. Sierau (berko.sierau@env.ethz.ch)

Received: 30 April 2015 - Published in Atmos. Chem. Phys. Discuss.: 1 June 2015

Revised: 14 October 2015 - Accepted: 20 October 2015 - Published: 4 November 2015 
Abstract. Cloud condensation nuclei counter (CCNC) measurements performed at 14 locations around the world within the European Integrated project on Aerosol Cloud Climate and Air Quality interactions (EUCAARI) framework have been analysed and discussed with respect to the cloud condensation nuclei $(\mathrm{CCN})$ activation and hygroscopic properties of the atmospheric aerosol. The annual mean ratio of activated cloud condensation nuclei $\left(N_{\mathrm{CCN}}\right)$ to the total number concentration of particles $\left(N_{\mathrm{CN}}\right)$, known as the activated fraction $A$, shows a similar functional dependence on supersaturation $S$ at many locations - exceptions to this being certain marine locations, a free troposphere site and background sites in south-west Germany and northern Finland. The use of total number concentration of particles above 50 and $100 \mathrm{~nm}$ diameter when calculating the activated fractions ( $A_{50}$ and $A_{100}$, respectively) renders a much more stable dependence of $A$ on $S ; A_{50}$ and $A_{100}$ also reveal the effect of the size distribution on $\mathrm{CCN}$ activation. With respect to chemical composition, it was found that the hygroscopicity of aerosol particles as a function of size differs among locations. The hygroscopicity parameter $\kappa$ decreased with an increasing size at a continental site in south-west Germany and fluctuated without any particular size dependence across the observed size range in the remote tropical North Atlantic and rural central Hungary. At all other locations $\kappa$ increased with size. In fact, in Hyytiälä, Vavihill, Jungfraujoch and Pallas the difference in hygroscopicity between Aitken and accumulation mode aerosol was statistically significant at the $5 \%$ significance level. In a boreal environment the assumption of a size-independent $\kappa$ can lead to a potentially substantial overestimation of $N_{\mathrm{CCN}}$ at $S$ levels above $0.6 \%$. The same is true for other locations where $\kappa$ was found to increase with size. While detailed information about aerosol hygroscopicity can significantly improve the prediction of $N_{\mathrm{CCN}}$, total aerosol number concentration and aerosol size distribution remain more important parameters. The seasonal and diurnal patterns of $\mathrm{CCN}$ activation and hygroscopic properties vary among three long-term locations, highlighting the spatial and temporal variability of potential aerosol-cloud interactions in various environments.

\section{Introduction}

Atmospheric aerosol particles are known to modify the microphysical properties of clouds, such as their albedo, lifetime and precipitation patterns (Boucher et al., 2013). Due to the importance of clouds in the weather and climate systems, these aerosol-induced changes, known as the indirect effects of aerosol on climate, are a subject of rigorous research. The quantification of the radiative forcing associated with the interactions of atmospheric aerosol with clouds remains one of the biggest challenges in the current understanding of cli- mate change (Boucher et al., 2013). These challenges are associated with the production of the aerosol particles that are able to activate into cloud droplets, known as cloud condensation nuclei (CCN) (e.g. Laaksonen et al., 2005; Andreae and Rosenfeld, 2008; Kuang et al., 2009; Kerminen et al., 2012), their actual activation into cloud drops (e.g. Kulmala et al., 1996; Dusek et al., 2006; McFiggans et al., 2006; Paramonov et al., 2013; Hammer et al., 2014), the formation of clouds (e.g. Twomey, 1959; Mason and Chien, 1962; Vaillancourt et al., 2002), time evolution of cloud microphysical and other properties (e.g. Rosenfeld et al., 2014) and the interaction of clouds with the solar and terrestrial radiation (e.g. Boucher and Lohmann, 1995; Ramanathan et al., 2001; Chen et al., 2014). A better understanding is needed with respect to each of these steps in order to improve the performance of the current global climate models (GCMs) and to increase the accuracy of the future climate predictions.

Several aerosol properties are of special interest when looking at the interaction of atmospheric aerosol particles with warm clouds. The current article focuses on the number, size and hygroscopicity of the atmospheric aerosol particles with regard to how these parameters affect the potential of particles to act as CCN. One such property of interest is the CCN number concentration $N_{\mathrm{CCN}}$. Depending on the location, $N_{\mathrm{CCN}}$ can vary by several orders of magnitude, and it directly depends on the aerosol properties and the ambient water vapour supersaturation ratio $S$ in the atmosphere. Köhler theory dictates that the minimum size at which particles activate into cloud drops decreases with increasing $S$ (Köhler, 1936); consequently $N_{\mathrm{CCN}}$ increases monotonically with $S$ for a given aerosol population. The exact response of $N_{\mathrm{CCN}}$ to an increasing $S$ depends on the total aerosol number concentration $N_{\mathrm{CN}}$, aerosol size distribution and particle hygroscopicity. Besides the relevant references found throughout the paper, discussion about $N_{\mathrm{CCN}}$ concentrations in various environments can be found in, e.g. Pandis et al. (1994), Covert et al. (1998), Snider and Brenguier (2000), Chang et al. (2007), Andreae and Rosenfeld (2008), Andreae (2009) and Wang et al. (2010). At any given $S$, another property of interest is the critical dry diameter of CCN activation $D_{\mathrm{c}}$, defined as the smallest diameter at which particles activate into cloud drops. For internally mixed polydisperse aerosol particles, this diameter indicates that in the presence of a sufficient amount of water vapour all particles above this size activate into cloud drops, and all particles below this size do not. However, atmospheric aerosol is frequently externally mixed, with particles of different sizes exhibiting different chemical composition, and, therefore, in practice, $D_{\mathrm{c}}$ is usually estimated as the diameter at which $50 \%$ of the particles activate and grow into cloud drops at any given $S$. $D_{\mathrm{c}}$ can be directly calculated from size-segregated cloud condensation nuclei counter (CCNC) measurements (Rose et al., 2008) or estimated from the size distribution data coupled with $N_{\mathrm{CCN}}$ 
(Hitzenberger et al., 2003; Furutani et al., 2008). The effect of hygroscopicity on the activation of $\mathrm{CCN}$ into cloud drops has also been studied extensively, and several simplified theoretical models have been suggested to link particle composition with critical supersaturation $S_{\mathrm{c}}$, i.e. the minimum $S$ required for the particles of a certain size to activate into cloud drops (e.g. Svenningsson et al., 1992; Rissler et al., 2005; Khvorostyanov and Curry, 2007; Wex et al., 2007). One such approach is the hygroscopicity parameter $\kappa$, also known as "kappa", a unitless number describing the cloud condensation nucleus activity (Petters and Kreidenweis, 2007). The value of $\kappa$ typically varies between zero and just above unity, with values close to zero indicating a non-hygroscopic aerosol, i.e. with low affinity for water (e.g. freshly emitted black carbon; e.g. Hudson et al., 1991; Weingartner et al., 1997; Wittbom et al., 2014) and values close to unity indicating an aerosol with high hygroscopicity, i.e. high affinity for water (e.g. sea salt particles; e.g. Good et al., 2010). Since its introduction, the parameter $\kappa$ has been used in CCN studies quite extensively (e.g. Carrico et al., 2008; Kammermann et al., 2010a; Levin et al., 2014).

This article summarises the measurements performed by CCNCs within the framework of the European Integrated project on Aerosol Cloud Climate and Air Quality interactions (EUCAARI). One of the EUCAARI project aims was to compile a comprehensive database of in situ measured aerosol, $\mathrm{CCN}$ and hygroscopic properties in order to increase the knowledge about aerosol-cloud-climate interactions and to combine the relevant existing measurement infrastructure (Kulmala et al., 2011). Besides CCNCs already deployed at the existing European long-term measurement stations, several intensive field campaigns using the $\mathrm{CCNC}$ were carried out as part of EUCAARI as well. The main objective of this work is to present a comprehensive overview and intercomparison of CCNC measurements and to provide an insight into the cloud droplet activation and aerosol hygroscopic properties in different environments. More specifically, the aims are to (i) get new insight into CCN number concentrations and activated fractions around the world and their dependence on the water vapour supersaturation ratio, (ii) provide new information about the dependence of aerosol hygroscopicity on particle size, and (iii) reveal seasonal and diurnal variation of $\mathrm{CCN}$ activation and hygroscopic properties. While undeniably important, the effect of size distribution on $N_{\mathrm{CCN}}$ and the size-resolved activated fraction (e.g. Dusek et al., 2006; Quinn et al., 2008; Morales Betancourt and Nenes, 2014) is not investigated herein, and an overview of the existing EUCAARI aerosol size distribution data can be found in Asmi et al. (2011) and Beddows et al. (2014).

\section{Methodology}

\subsection{Instrumentation}

A CCNC is a type of instrument frequently used for studying the cloud droplet activation potential of aerosol particles. In its simplest set-up, a CCNC consists of a saturator unit and an optical particle counter (OPC) frequently running in parallel with a condensation particle counter (CPC). For all measurements presented herein, the CCNC used was a commercially available instrument produced by Droplet Measurement Technologies, Inc. (DMT-CCNC), the basic principles of operation of which are described below.

Upon entering the measurement set-up, the aerosol flow is split into two sample flows, with the first flow leading to a CPC to determine the total particle number concentration, hereafter referred to as $N_{\mathrm{CN}}$. The second flow feeds the aerosol into the saturator unit of the CCNC, inside of which the conditions of supersaturation $S_{\text {eff }}$ with respect to water vapour down the centre of the column are established. Aerosol, flowing under laminar flow conditions, is subjected to these supersaturation conditions, during which particles with a critical supersaturation $S_{\mathrm{c}}$ smaller than $S_{\text {eff }}$ will grow by the condensation of water vapour and remain in stable equilibrium, i.e. activate as $\mathrm{CCN}$. The residence time inside the saturator column $(\sim 10 \mathrm{~s})$ allows for the activated particles to grow to sizes larger than $1 \mu \mathrm{m}$ in diameter; these particles are then counted by the OPC providing the number concentration of activated aerosol particles, a quantity hereafter referred to as $N_{\mathrm{CCN}}$. The described set-up is characteristic of polydisperse measurements; an inclusion of a drier, a neutraliser and a differential mobility analyzer (DMA; Knutson and Whitby, 1975) prior to the splitting of the flow into two parallel lines allows for the selection of a particular particle size, i.e. quasi-monodisperse measurements. Such measurements can be performed either by varying the particle size at a constant $S_{\text {eff }}\left(D\right.$-scan) or by varying $S_{\text {eff }}$ at a constant particle size ( $S$-scan). Such a set-up, while more complex, provides activation spectra and allows for a direct calculation of the critical dry diameter of droplet activation $D_{\mathrm{c}}$ (in case of the $D$-scan) or the critical supersaturation $S_{\mathrm{c}}$ (in case of the $S$-scan). Typically, a CCNC operates at several different levels of $S_{\text {eff }}$, most commonly ranging between 0.1 and $1.0 \%$; the deviations from the nominal assigned $S_{\text {eff }}$ values can be monitored and corrected by applying a standardised calibration procedure, as described in Sect. 2.3. A more detailed description of the general operating procedures of the CCNC can be found in Roberts and Nenes (2005); exact details of the measurement set-up at each of the locations described in the next section can be found in the respective published literature referenced throughout the text. 


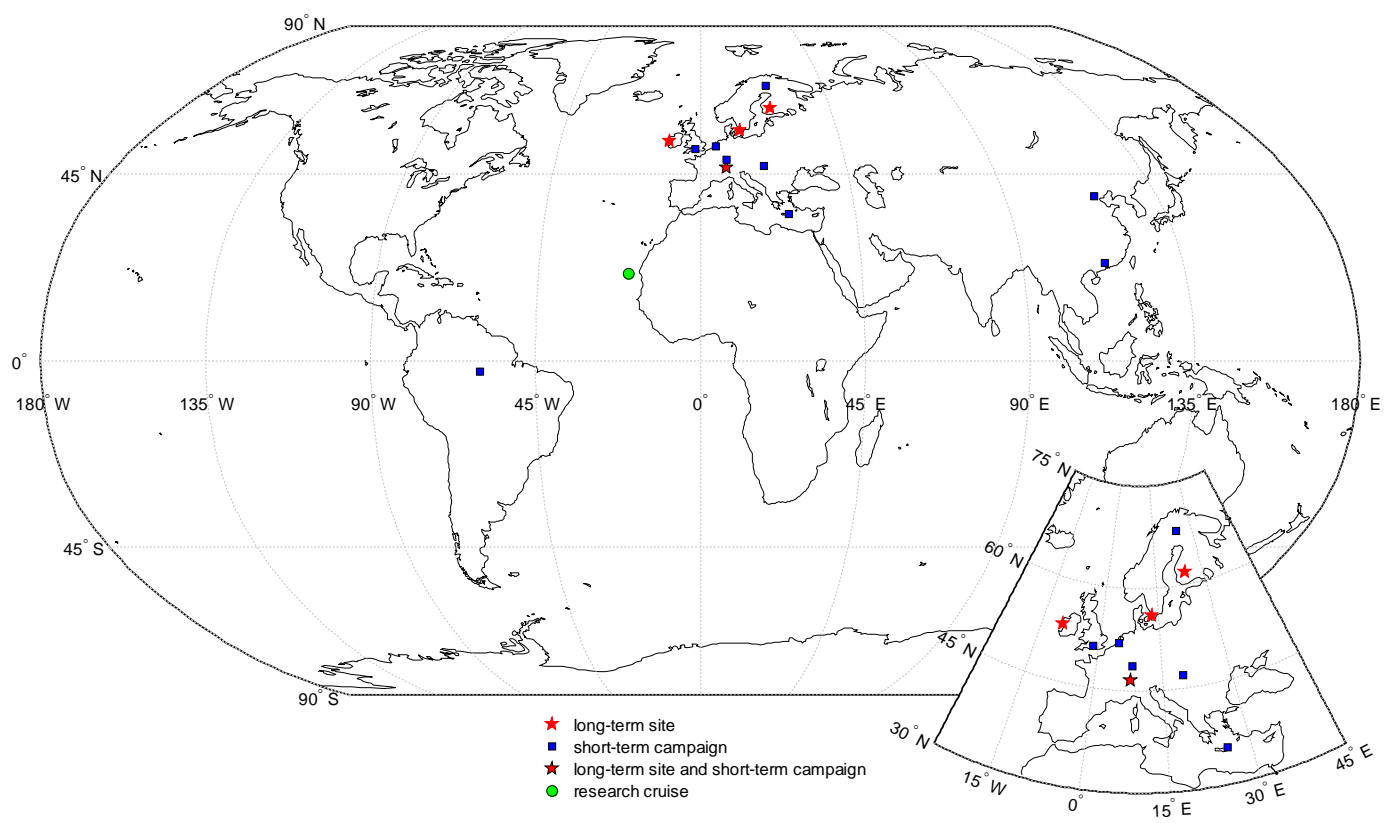

Figure 1. A world map showing the locations of CCNC measurements performed during EUCAARI and presented in this study.

Table 1. Names, locations and descriptions of all measurement sites presented in the analysis.

\begin{tabular}{|c|c|c|c|c|}
\hline Name of station or campaign & Location & Geographic coordinates & $\begin{array}{l}\text { Elevation } \\
\text { (m a.m.s.l.) }\end{array}$ & Site description \\
\hline Hyytiälä & southern Finland & $61^{\circ} 51^{\prime} \mathrm{N}, 24^{\circ} 17^{\prime} \mathrm{E}$ & 181 & rural background \\
\hline Vavihill & southern Sweden & $56^{\circ} 01^{\prime} \mathrm{N}, 13^{\circ} 09^{\prime} \mathrm{E}$ & 172 & rural background \\
\hline Jungfraujoch/CLACE-6 & Swiss Alps & $46^{\circ} 33^{\prime} \mathrm{N}, 07^{\circ} 59^{\prime} \mathrm{E}$ & 3580 & free troposphere \\
\hline Mace Head & west coast of Ireland & $53^{\circ} 19^{\prime} \mathrm{N}, 09^{\circ} 54^{\prime} \mathrm{W}$ & 0 & coastal background \\
\hline Pallas & northern Finland & $67^{\circ} 58^{\prime} \mathrm{N}, 24^{\circ} 07^{\prime} \mathrm{E}$ & 560 & remote background \\
\hline Finokalia & northern Crete & $35^{\circ} 20^{\prime} \mathrm{N}, 25^{\circ} 40^{\prime} \mathrm{E}$ & 250 & remote coastal \\
\hline Cabauw & central Netherlands & $51^{\circ} 58^{\prime} \mathrm{N}, 04^{\circ} 56^{\prime} \mathrm{E}$ & -1 & rural background \\
\hline K-puszta & central Hungary & $46^{\circ} 58^{\prime} \mathrm{N}, 19^{\circ} 33^{\prime} \mathrm{E}$ & 125 & rural \\
\hline Chilbolton & southern United Kingdom & $51^{\circ} 09^{\prime} \mathrm{N}, 01^{\circ} 26^{\prime} \mathrm{W}$ & 78 & continental background \\
\hline COPS & south-west Germany & $48^{\circ} 36^{\prime} \mathrm{N}, 08^{\circ} 12^{\prime} \mathrm{E}$ & 1156 & continental background \\
\hline RHaMBLe & tropical North Atlantic & $\sim 21^{\circ} \mathrm{N}, 20^{\circ} \mathrm{W}$ & 0 & remote marine \\
\hline PRIDE-PRD2006 & southeastern China & $23^{\circ} 33^{\prime} \mathrm{N}, 113^{\circ} 04^{\prime} \mathrm{E}$ & 28 & rural background \\
\hline AMAZE-08 & northern Brazil & $02^{\circ} 36^{\prime} \mathrm{S}, 60^{\circ} 13^{\prime} \mathrm{W}$ & 108 & remote background \\
\hline CAREBeijing-2006 & northern China & $39^{\circ} 31^{\prime} \mathrm{N}, 116^{\circ} 18^{\prime} \mathrm{E}$ & 30 & suburban \\
\hline
\end{tabular}

\subsection{Measurement sites}

Data from a total of 14 EUCAARI locations have been provided for this analysis, including both long-term measurement stations and short-term campaigns (Fig. 1). As seen in the figure, data sets came from a wide variety of locations representing various environments, including marine and continental, urban and background, at altitudes ranging from the ground level to the free troposphere. The location and description of each measurement site are given in Table 1. All measurements presented herein were performed within the EUCAARI framework.
Hyytiälä Forestry Field Station in southern Finland is the location of the Station for Measuring EcosystemAtmosphere Relations (SMEAR II), operated by the University of Helsinki. Located on a flat terrain and surrounded by the boreal coniferous forest, mainly Scots pine, the station is well representative of the boreal environment (Hari and Kulmala, 2005). It is a rural background site, with the nearest city of Tampere (population 220000 ) located $50 \mathrm{~km}$ to the south-west. Air masses at the site can be of both Arctic and European origin; however, aerosol particle number concentrations at this site are typically low (Sogacheva et al., 2005). 
Vavihill in southern Sweden is a continental background site surrounded by grasslands and deciduous forest and operated by Lund University. The site is located $60-70 \mathrm{~km}$ NNE of the Malmö and Copenhagen urban area (population $\sim 2000000$ ); however, it is considered to not be affected by the local anthropogenic sources (Tunved et al., 2003). Due to its location, the site is often used for monitoring the transport of pollution from continental Europe into the Nordic region (Tunved et al., 2003).

The Jungfraujoch is a high Alpine station in the Bernese Alps in Switzerland, where the aerosol measurements are performed by the Paul Scherrer Institute (PSI). Being located high in the mountains ( $3580 \mathrm{~m}$ a.s.1.), the station is far from local sources of pollution and is, in fact, in the free troposphere most of the time; hence, it is considered a continental background site and aerosol concentrations are very low (Collaud Coen et al., 2011). However, particularly during the summer months, the Jungfraujoch site is frequently influenced by the injections of more polluted air from the planetary boundary layer, driven by thermal convection (Jurányi et al., 2010, 2011; Kammermann et al., 2010a). The station is frequently inside clouds allowing for direct measurements of aerosol-cloud interactions.

Mace Head is a coastal marine site located on the west coast of Ireland and operated by the National University of Ireland, Galway. The distance to the nearest urban settlement of Galway City ( $88 \mathrm{~km}$, population 65000) renders Mace Head a clean background site; being on the coast, the station is directly exposed to the North Atlantic Ocean. Occasionally the station is subject to more polluted air masses originating from continental Europe and the United Kingdom (O'Dowd et al., 2014).

Pallas is a remote continental site in northern Finland located in the northernmost boreal forest zone in Europe; it is run by the Finnish Meteorological Institute (FMI). The station is situated on top of a treeless hill and, due to the frequent presence of clouds, is suitable for in situ measurements of aerosol-cloud interactions. The Pallas station is subject to both clean Arctic air masses, as well as to more polluted European air masses; regardless, absolute particle number concentrations are typically low (Hatakka et al., 2003).

Finokalia station is a remote coastal site located on the island of Crete and operated by the University of Crete. The station is located on top of a hill, and most frequently air masses arrive in Finokalia over the Mediterranean Sea (Stock et al., 2011). The station is representative of background conditions as there are no local sources of pollution present; the largest nearby urban centre of Heraklion (population 175000 ) is $50 \mathrm{~km}$ to the west.

The Cabauw Experimental Site for Atmospheric Research (CESAR) is located in the central Netherlands, $44 \mathrm{~km}$ from the North Sea. The station is in a rural area; however, the big cities of Utrecht and Rotterdam are nearby; the station is subject to both continental and maritime conditions (Mensah et al., 2012). The station is operated by the Royal Netherlands Meteorological Institute (KNMI).

The University of Manchester conducted four shortterm measurement campaigns utilising a CCNC: K-puszta, Chilbolton, COPS and RHaMBLe. K-puszta is a rural site surrounded by deciduous-coniferous forest located on the Great Hungarian Plain in central Hungary $80 \mathrm{~km}$ SE of Budapest. The site has no local anthropogenic pollution sources (Ion et al., 2005). Chilbolton is also a rural site, located in southern United Kingdom, $100 \mathrm{~km}$ WSW of London. The site is most frequently influenced by the marine air masses; a potential local source of anthropogenic pollution is the seasonal agricultural spraying (Campanelli et al., 2012). The Convective and Orographically-induced Precipitation Study (COPS) campaign took place at the top of the Hornisgrinde Mountain in the Black Forest region of south-west Germany. While this site is primarily surrounded by the coniferous forest, the close proximity to the Rhine Valley exposes the site to some anthropogenic pollution. Due to its elevation, the site is occasionally in the free troposphere (Jones et al., 2011). The Reactive Halogens in the Marine Boundary Layer (RHaMBLe) Discovery Cruise D319 campaign was a cruise conducted in the tropical North Atlantic between Portugal and Cabo Verde. The operational area can be described as a remote marine environment with few, if any, sources of anthropogenic pollution. Air masses can originate from both the ocean and from the African mainland (Good et al., 2010).

The Max Planck Institute for Chemistry (MPIC) also conducted four CCNC measurement campaigns within the EUCAARI framework: PRIDE-PRD2006, AMAZE-08, CAREBeijing-2006 and CLACE-6, with the last one having taken place at the previously described Jungfraujoch station. The PRIDE-PRD2006 campaign took place in southeastern China, in a small village $\sim 60 \mathrm{~km} \mathrm{NW}$ of Guangzhou, in the vicinity of a densely populated urban centre. The wind direction during the campaign rendered the site a rural receptor of the regional pollution originating from the Guangzhou urban cluster (Rose et al., 2010). The AMAZE-08 campaign took place at a remote site in an Amazonian rainforest, $60 \mathrm{~km}$ NNW of Manaus, Brazil. During the campaign, the site experienced air masses characteristic of clean tropical rainforest conditions as well as air masses influenced by long-range transport of pollution (Gunthe et al., 2009; Martin et al., 2010). The CAREBeijing-2006 campaign was conducted at a suburban site in northern China, on the grounds of Huang $\mathrm{Pu}$ University in Yufa, $\sim 50 \mathrm{~km}$ south of Beijing. The site is subject to air masses originating both in the south and in the north; however, being located on the outskirts of a large urban centre, particle concentrations are generally high (Garland et al., 2009).

\subsection{Data}

The measurement period for each location and a brief summary of available CCNC data are presented in Fig. 2 and 


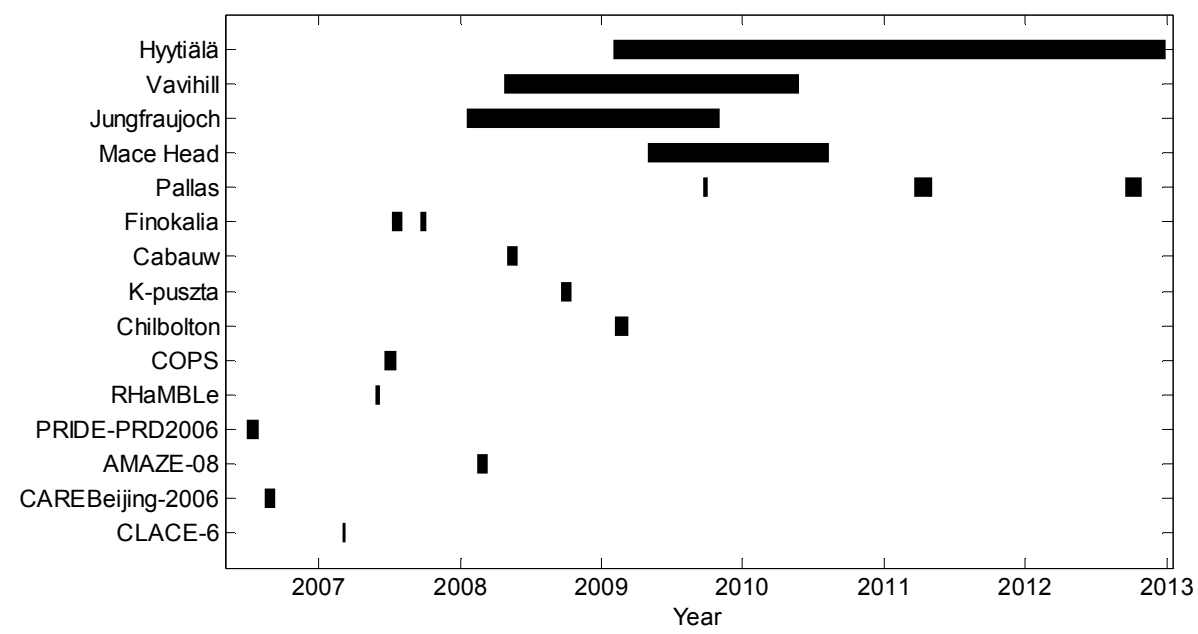

Figure 2. Periods of available data for all locations and campaigns.

Table 2, respectively. Available data range from mid-2006 to the end of 2012; the four long-term data sets all exceed one year in duration. As originally requested by the authors from the EUCAARI partners, some of the data were submitted in the NASA-Ames format with daily and monthly/campaign averages. Other data sets were submitted in the original time resolution and have been compiled accordingly for this overview study.

For the quality assurance of the $\mathrm{CCNC}$ data, data providers were requested to recalculate all values to correspond to the standard temperature and pressure and to utilise a consistent procedure for the $\mathrm{CCNC}$ calibration. Calibrations were asked to be performed as outlined in Rose et al. (2008) using nebulised, dried, charge-equilibrated and size-selected ammonium sulphate or sodium chloride aerosol particles. To predict $S_{\text {eff }}$ for instrument calibration, water activity was asked to be parameterised according to either the AIM-based model (Rose et al., 2008) or the ADDEM model (Topping, 2005); both of these models can be considered as accurate sources of water activity data, and the discussion about their associated uncertainties can be found in the corresponding references. As none of the participating data providers noted a deviation from the calibration procedure, it is assumed that the data were treated accordingly. However, deviations from the described procedure and from the target $S_{\text {eff }}$ levels may be possible and can potentially affect some of the conclusions presented in this paper. Uncertainties associated with deviations from the mentioned calibration procedure and parameterisation are discussed in great detail in Rose et al. (2008) and Topping (2005).

For some of the polydisperse data sets, where available, differential/scanning mobility particle sizer (DMPS/SMPS; Wang and Flagan, 1989; Wiedensohler et al., 2012) data were used in conjunction with the CCNC to derive the critical dry diameter $D_{\mathrm{c}}$. The procedure was carried out by comparing $N_{\mathrm{CCN}}$ to the DMPS/SMPS-derived number size distribu- tions; these were integrated from the largest size bin until the cumulative $N_{\mathrm{CN}}$ concentration was equal to $N_{\mathrm{CCN}}$. $D_{\mathrm{c}}$ was then calculated by interpolating between the two adjacent size bins (Furutani et al., 2008). Following the calculation of $D_{\mathrm{c}}$, the hygroscopicity parameter $\kappa$ was determined using the effective hygroscopicity parameter (EH1) Köhler model (Eq. 1) assuming the surface tension of pure water (Petters and Kreidenweis, 2007; Rose et al., 2008). Due to the surface tension of actual cloud droplets being lower than that of pure water droplets (Facchini et al., 2000), this assumption, although commonly used, typically leads to an overestimation of the $N_{\mathrm{CCN}}$ (Kammermann et al., 2010b).

$S=\frac{D_{\mathrm{wet}}^{3}-D_{\mathrm{s}}^{3}}{D_{\mathrm{wet}}^{3}-D_{\mathrm{s}}^{3}(1-\kappa)} \exp \left(\frac{4 \sigma_{\mathrm{sol}} M_{\mathrm{w}}}{R T \rho_{\mathrm{w}} D_{\mathrm{wet}}}\right)$,

where $S$ is water vapour saturation ratio, $D_{\text {wet }}$ is the droplet diameter, $D_{\mathrm{s}}$ is the dry particle diameter, which, as per Rose et al. (2008), can be substituted with $D_{\mathrm{c}}, \kappa$ is the hygroscopicity parameter, $\sigma_{\text {sol }}$ is the surface tension of condensing solution (assumed to be pure water), $M_{\mathrm{w}}$ is the molar mass of water, $R$ is the universal gas constant, $T$ is the absolute temperature and $\rho_{\mathrm{w}}$ is the density of pure water.

For certain sites, total number concentrations of particles larger than 50 or $100 \mathrm{~nm}$ in diameter $\left(N_{50}\right.$ or $\left.N_{100}\right)$ were calculated from the corresponding DMPS or SMPS data.

In order to compare the results from different stations, several interpolation/extrapolation techniques were used. All $N_{\mathrm{CCN}}$ concentrations were averaged for each site for each $S_{\text {eff }}$ level and then recalculated to correspond to the target $S_{\text {eff }}$ levels suggested by the Aerosols, Clouds and Trace gases Research InfraStructure (ACTRIS) Network: 0.1, 0.2, $0.3,0.5$ and $1.0 \%$. Recalculation to the nearest target supersaturation was accomplished by a simple linear interpolation/extrapolation of $N_{\mathrm{CCN}}$ as a function of $S_{\text {eff }}$ using the two adjacent/nearest $S_{\text {eff }}$ points. For the Jungfraujoch data, 
Table 2. Summary of available data for each measurement location. $N_{\mathrm{CCN}}$ is the $\mathrm{CCN}$ number concentration, $N_{\mathrm{CN}}$ is the total number concentration, $A$ is the activated fraction, $D_{\mathrm{c}}$ is the critical dry diameter and $\kappa$ is the hygroscopicity parameter. The "set-up" column indicates whether the CCNC was operating in polydisperse or monodisperse mode. $D_{\text {c_calc }}$ and $\kappa_{-}$calc have been calculated from polydisperse data using the differential/scanning mobility particle sizer (DMPS/SMPS) data.

\begin{tabular}{|c|c|c|c|c|c|}
\hline Name of station or campaign & Set-up & Parameters & $S_{\text {eff levels }}$ & Time resolution & Reference \\
\hline Hyytiälä & poly \& mono & $N_{\mathrm{CN}}, N_{\mathrm{CCN}}, A, D_{\mathrm{c}}, \kappa$ & 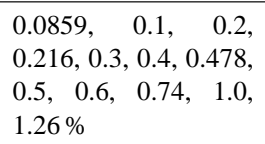 & original & Paramonov et al. (2013) \\
\hline Vavihill & poly & $N_{\mathrm{CCN}}, N_{\mathrm{CN}}, A, D_{\mathrm{c} \_ \text {calc }}, \kappa_{-}$calc & $\begin{array}{llll}0.1, & 0.2, & 0.4, & 0.7 \\
1.0 \% & \end{array}$ & original & Fors et al. (2011) \\
\hline Jungfraujoch & poly & $N_{\mathrm{CCN}}, N_{\mathrm{CN}}, A, D_{\text {c_calc }}, \kappa_{-}$calc & $\begin{array}{l}0.12,0.24,0.35,0.47, \\
0.59,0.71,0.83,0.95, \\
1.07,1.18 \%\end{array}$ & original & Jurányi et al. $(2010,2011)$ \\
\hline Mace Head & poly & $N_{\mathrm{CN}}, N_{\mathrm{CCN}}, A$ & $0.25,0.5,0.75 \%$ & averaged & Ovadnevaite et al. (2011) \\
\hline Pallas A & poly & $N_{\mathrm{CCN}}, N_{\mathrm{CN}}, A, D_{\text {c_calc }}, \kappa_{-}$calc & 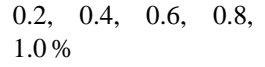 & original & Jaatinen et al. (2014) \\
\hline Pallas B & poly \& mono & $N_{\mathrm{CN}}, N_{\mathrm{CCN}}, A, D_{\mathrm{c}}, \kappa$ & $\begin{array}{lll}0.47, & 0.72, & 0.97 \\
1.22 \% & \end{array}$ & $\begin{array}{l}\text { averaged (poly), } \\
\text { original (mono) }\end{array}$ & $\mathrm{n} / \mathrm{a}$ \\
\hline Pallas C & poly \& mono & $N_{\mathrm{CN}}, N_{\mathrm{CCN}}, A, D_{\mathrm{c}}, \kappa$ & 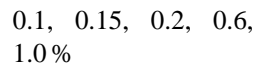 & $\begin{array}{l}\text { averaged (poly), } \\
\text { original (mono) }\end{array}$ & Brus et al. (2013) \\
\hline Finokalia A & mono & $N_{\mathrm{CN}}, N_{\mathrm{CCN}}, D_{\mathrm{c}}$ & $\begin{array}{l}0.21,0.38,0.52,0.66 \\
0.73 \%\end{array}$ & averaged & Bougiatioti et al. (2009) \\
\hline Finokalia B & poly & $N_{\mathrm{CCN}}, A, D_{\mathrm{c}_{-} \text {calc }}$ & $\begin{array}{l}0.21,0.38,0.52,0.66 \\
0.73 \%\end{array}$ & averaged & Bougiatioti et al. (2009) \\
\hline Cabauw & poly & $N_{\mathrm{CCN}}$ & $\begin{array}{l}\text { varies between } 0.1 \\
\text { and } 1.0 \%\end{array}$ & original & Bègue (2012) \\
\hline K-puszta & mono & $N_{\mathrm{CCN}}, A, \kappa$ & $\begin{array}{l}0.03,0.04,0.10,0.17, \\
0.20,0.25,0.44,0.62, \\
0.67 \%\end{array}$ & averaged & $\mathrm{n} / \mathrm{a}$ \\
\hline Chilbolton & mono & $N_{\mathrm{CCN}}, A, D_{\mathrm{c}}, \kappa$ & $\begin{array}{lll}0.11, & 0.30, & 0.56 \\
0.94 \% & \end{array}$ & averaged & Whitehead et al. (2014) \\
\hline COPS & poly \& mono & $N_{\mathrm{CCN}}, A, D_{\mathrm{c}}, \kappa$ & $\begin{array}{l}0.11,0.17,0.24,0.28, \\
0.32,0.35,0.43,0.50, \\
0.65,0.80 \%\end{array}$ & averaged & $\begin{array}{l}\text { Irwin et al. (2010), Jones } \\
\text { et al. (2011), Whitehead et } \\
\text { al. (2014) }\end{array}$ \\
\hline RHaMBLe & poly \& mono & $N_{\mathrm{CCN}}, A, D_{\mathrm{c}}, \kappa$ & $\begin{array}{l}0.09,0.16,0.29,0.47 \\
0.74 \%\end{array}$ & averaged & $\begin{array}{l}\text { Good et al. (2010), White- } \\
\text { head et al. (2014) }\end{array}$ \\
\hline PRIDE-PRD2006 & mono & $N_{\mathrm{CN}}, N_{\mathrm{CCN}}, A, D_{\mathrm{c}}, \kappa$ & $\begin{array}{l}0.068, \quad 0.27, \quad 0.47 \\
0.67,0.87,1.27 \%\end{array}$ & original & Rose et al. $(2010,2011)$ \\
\hline AMAZE-08 & mono & $N_{\mathrm{CN}}, N_{\mathrm{CCN}}, A, D_{\mathrm{c}}, \kappa$ & $\begin{array}{l}0.095, \quad 0.19, \quad 0.28 \\
0.46,0.82 \%\end{array}$ & original & Gunthe et al. (2009) \\
\hline CAREBeijing-2006 & mono & $N_{\mathrm{CN}}, N_{\mathrm{CCN}}, A, D_{\mathrm{c}}, \kappa$ & $\begin{array}{l}0.066, \quad 0.26, \quad 0.46 \\
0.66,0.86 \%\end{array}$ & original & Gunthe et al. (2011) \\
\hline CLACE-6 & mono & $N_{\mathrm{CN}}, N_{\mathrm{CCN}}, A, D_{\mathrm{c}}, \kappa$ & $\begin{array}{l}0.079, \quad 0.17, \quad 0.27 \\
0.46,0.66 \%\end{array}$ & original & Rose et al. (2013) \\
\hline
\end{tabular}

$D_{\text {c }}$ at $S_{\text {eff }}$ of 0.12 and $0.95 \%$ was recalculated to the corresponding $D_{\mathrm{c}}$ at the target $S_{\text {eff }}$ of 0.1 and $1.0 \%$, respectively, assuming a size-independent $\kappa$.

\section{Results and discussion}

\subsection{CCN concentrations}

Table 3 presents $\mathrm{CCN}$ number concentrations $N_{\mathrm{CCN}}$ at all 18 measurements locations and campaigns for five $S_{\text {eff }}$ levels mentioned in the previous section. First and foremost, since $\mathrm{CCN}$ are simply a fraction of the total aerosol population with their concentration depending on $S_{\text {eff }}, N_{\mathrm{CCN}}$ values at $S_{\text {eff }}$ of $1.0 \%$ follow a similar pattern known from to- tal particle number concentrations. The lowest $N_{\mathrm{CCN}}$ values, thus, originate in remote and clean locations, such as Pallas, the Amazonian rainforest (AMAZE-08), Jungfraujoch and Chilbolton. The highest $N_{\mathrm{CCN}}$ values are found in more polluted locations - CAREBeijing-2006 and PRIDE-

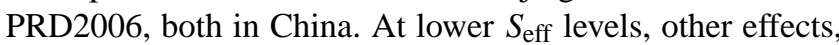
such as those of size distribution and hygroscopicity, become more pronounced. When examining $N_{\mathrm{CCN}}$ at $S_{\text {eff }}$ of $0.1 \%$, the highest values are still found in China; similar to $N_{\mathrm{CCN}}$ at $S_{\text {eff }}$ of $1.0 \%$, the lowest values are found in Pallas, the Amazonian rainforest (AMAZE-08), Jungfraujoch and also in south-west Germany (COPS).

In order to examine the $\mathrm{CCN}$ activation spectra in more detail, Fig. 3 presents cumulative $N_{\mathrm{CCN}}$ concentrations shown 
Table 3. Average $N_{\mathrm{CCN}}$ concentrations $\left(\mathrm{cm}^{-3}\right)$ at all studied locations. All $N_{\mathrm{CCN}}$ concentrations were recalculated to correspond to the $S_{\text {eff }}$ levels suggested by the ACTRIS network: $0.1,0.2,0.3,0.5$ and $1.0 \%$. The four long-term data sets are shown at the top of the table.

\begin{tabular}{lccccc}
\hline Name of station or campaign & $S_{\text {eff }}=0.1 \%$ & $S_{\text {eff }}=0.2 \%$ & $S_{\text {eff }}=0.3 \%$ & $S_{\text {eff }}=0.5 \%$ & $S_{\text {eff }}=1.0 \%$ \\
\hline Vavihill & 362 & 745 & 952 & 1285 & 1795 \\
Hyytiälä & 274 & 407 & 526 & 824 & 1128 \\
Mace Head & 472 & 526 & 581 & 691 & 1007 \\
Jungfraujoch & 135 & 249 & 341 & 444 & 599 \\
\hline PRIDE-PRD2006 & 1888 & 4594 & 6956 & 9760 & 13855 \\
CAREBeijing-2006 & 2547 & 4751 & 6510 & 8460 & 10711 \\
Cabauw & 435 & 1607 & 2208 & 3235 & 6439 \\
Finokalia B & 903 & 1167 & 1431 & 1793 & 2354 \\
Finokalia A & 946 & 1257 & 1567 & 1882 & 2109 \\
COPS & 3 & 210 & 364 & 710 & - \\
RHaMBLe & 300 & 535 & 717 & 922 & 1153 \\
K-puszta & 146 & 349 & 512 & 727 & 834 \\
Chilbolton & 145 & 210 & 274 & 384 & 506 \\
CLACE-6 & 66 & 126 & 156 & 205 & 303 \\
Pallas B & - & - & 149 & 176 & 247 \\
AMAZE-08 & 37 & 85 & 112 & 136 & 205 \\
Pallas C & 14 & 38 & 50 & 74 & 141 \\
Pallas A & 7 & 19 & 31 & 50 & 98 \\
\hline
\end{tabular}

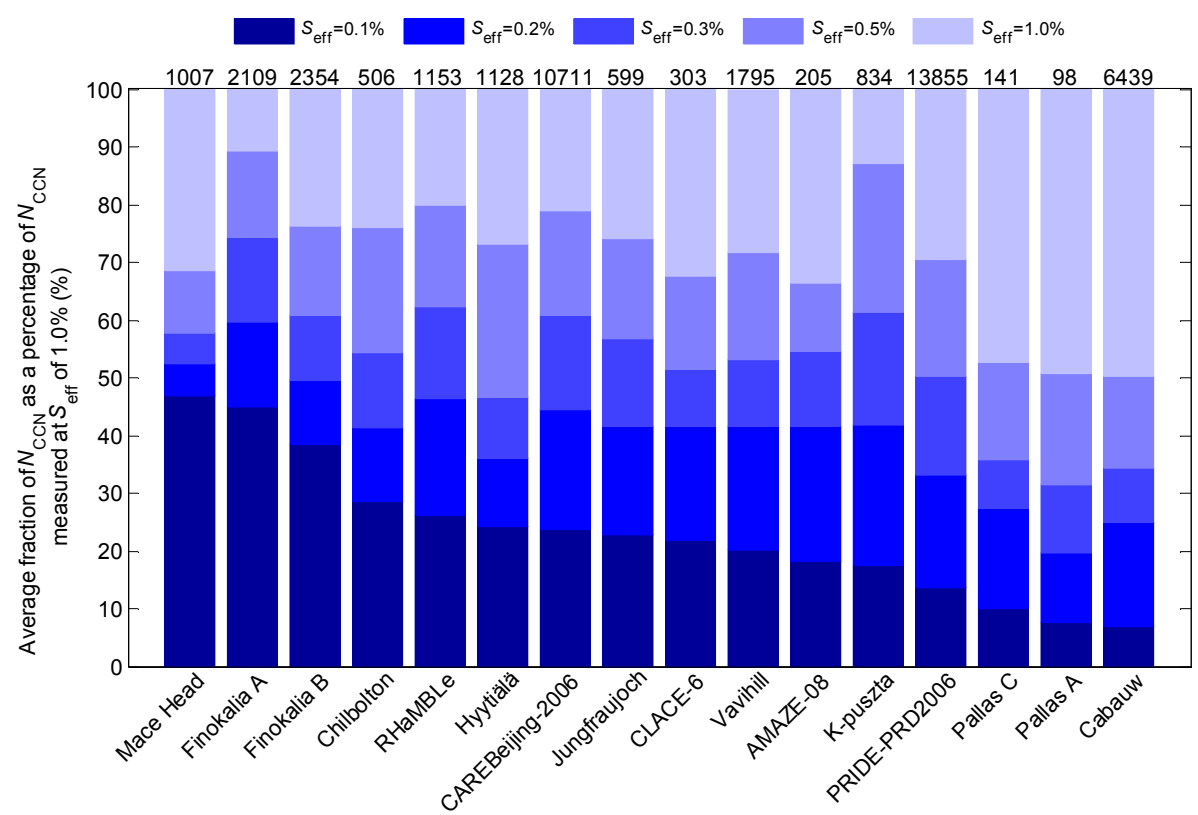

Figure 3. Average cumulative $N_{\mathrm{CCN}}$ for all available locations shown as a percentage of the $N_{\mathrm{CCN}}$ measured at the $S_{\text {eff }}$ of $1.0 \%$ (above each bar). Colours indicate the supersaturation $S_{\text {eff }}$ bins.

as a percentage of the $N_{\mathrm{CCN}}$ measured at the highest $S_{\text {eff }}$ of $1.0 \%$. One group of locations that can be pointed out in the figure is representative of the marine environment: Finokalia, Mace Head and the RHaMBLe campaign. At these marine locations the presence of large and hygroscopic sea salt particles is expected, and a large fraction of particles already activates at the lowest $S_{\text {eff }}$, i.e. of the total $N_{\mathrm{CCN}}$ measured at the highest $S_{\text {eff }}$, about a third activates already at the low-

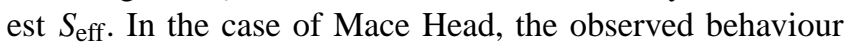
is due to the presence of sea salt particles and a peculiar organic composition of the marine aerosol (Ovadnevaite et al., 2011). Additionally, both Finokalia and Mace Head have a large fraction of the long-range transported and aged aerosol (Bougiatioti et al., 2009; Ovadnevaite et al., 2011), which has 


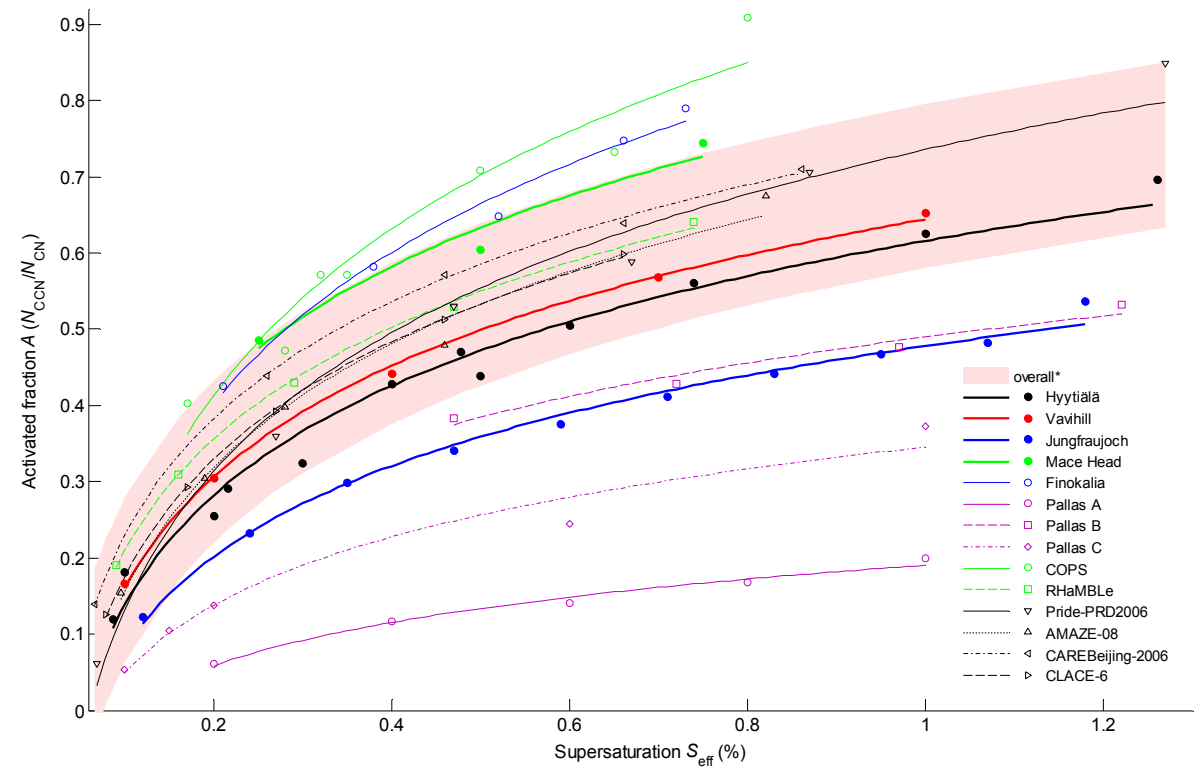

Figure 4. Average activated fraction $A$ as a function of supersaturation $S_{\text {eff }}$ for all available data sets. Symbols represent arithmetic mean

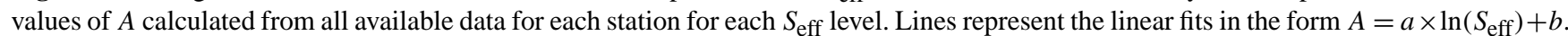
Also shown is the overall fit based on most of the data points (*Finokalia, COPS, Jungfraujoch and Pallas A, B and C data sets excluded). The shading of the overall fit represents the prediction bounds of the fit with a confidence level of $95 \%$. Slope, intercept and correlation coefficient values of the linear fits can be found in Table 4.

been shown to increase particle hygroscopicity (Perry et al., 2004; Furutani et al., 2008). Chilbolton, being a continental background site representative of the regional aerosol properties, also belongs to this group; however, the $N_{\mathrm{CCN}}$ concentrations at this location may be underestimated due to the aerosol not being dried prior to entering the $\mathrm{CCNC}$ (Whitehead et al., 2014).

Another group of locations with a different CCN activation pattern is represented by Pallas and Cabauw - at these locations very few particles activate at the lowest $S_{\text {eff }}$, and the $N_{\mathrm{CCN}}$ increases drastically when $S_{\text {eff }}$ changes from 0.5 to $1.0 \%$. This may indicate that the aerosol is dominated by the Aitken mode particles and, to a lesser extent, that the aerosol may be of low hygroscopicity. A high concentration of Aitken mode particles in the autumn and low aerosol hygroscopicity in Pallas have been previously reported by Tunved et al. (2003) and Komppula et al. (2006), respectively. The two measurement locations discussed here are interesting with regard to the ratio of presumed cloud droplet number concentration (CDNC) to the total aerosol particle number concentration. It has been reported that, although under the clean and convective conditions ambient $S_{\mathrm{c}}$ may reach as high as $1.0 \%$, in the polluted boundary layer $S_{\mathrm{c}}$ usually remains below $0.3 \%$ (Ditas et al., 2012; Hammer et al., 2014; Hudson and Noble, 2014). If one assumes this value, a comparatively small fraction of aerosol in northern Finland and central Netherlands would potentially activate into cloud droplets if exposed to this $S_{\mathrm{c}}$. This has direct implications for the cloud formation and, thus, local climate at these locations.

\subsection{Activated fraction}

Another variable describing $\mathrm{CCN}$ activation properties of an aerosol population that was examined for the majority of locations is the activated fraction $A$ calculated as a ratio of $N_{\mathrm{CCN}}$ to $N_{\mathrm{CN}}$ (Fig. 4). Each activation curve in Fig. 4 is based on the arithmetic mean values of $A$ calculated from all available data for each station for each $S_{\text {eff }}$ level. Included in the figure is the overall fit shown with prediction bounds (95\% confidence level) based on most of the activation curves, except the outlying ones of Finokalia, COPS, Jungfraujoch and Pallas A, B and C. As can be seen in the figure from the similar shape and placement of the activation curves and in Table 4 from the similar slope and intercept values, for many locations there is no discernible difference in how $A$ responds to changing $S_{\text {eff }}$ on an annual basis; this is further signified by the prediction bounds of the overall fit. Therefore, the average total number concentration $N_{\mathrm{CN}}$ alone is sufficient in order to roughly estimate the annual mean $N_{\mathrm{CCN}}$ at any given $S_{\text {eff }}$, for example, using the overall fit parameters presented in Table 4. The appropriateness of the overall fit for estimating $N_{\mathrm{CCN}}$ based on $N_{\mathrm{CN}}$ alone was investigated for the whole Hyytiälä data set, by comparing the $N_{\mathrm{CCN}}$ measured by the CCNC with the $N_{\mathrm{CCN}}$ calculated using the $N_{\mathrm{CN}}$ and the overall fit presented in Table 4. Such a comparison revealed that for Hyytiälä the overall fit leads to an annual 
Table 4. Parameters of the linear fit $A=a \times \ln \left(S_{\text {eff }}\right)+b$, for all locations depicted in Fig. 4. $a$ is the slope, $b$ is the intercept and $r$ is the correlation coefficient of the simple linear regression. The overall linear fit is based on most of the activation curves depicted in Fig. 4, except Finokalia, COPS, Jungfraujoch and Pallas A, B and $\mathrm{C}$.

\begin{tabular}{lccc}
\hline Name of station or campaign & $a$ & $b$ & $r$ \\
\hline Hyytiälä & 0.21 & 0.62 & 0.99 \\
Vavihill & 0.21 & 0.64 & 1.00 \\
Jungfraujoch & 0.17 & 0.48 & 1.00 \\
Mace Head & 0.23 & 0.79 & 0.98 \\
Finokalia & 0.29 & 0.86 & 0.99 \\
Pallas A & 0.08 & 0.19 & 0.99 \\
Pallas B & 0.15 & 0.49 & 0.98 \\
Pallas C & 0.13 & 0.35 & 0.98 \\
COPS & 0.31 & 0.92 & 0.97 \\
RHaMBLe & 0.21 & 0.70 & 1.00 \\
Pride-PRD2006 & 0.26 & 0.74 & 0.99 \\
AMAZE-08 & 0.23 & 0.70 & 0.99 \\
CARE-Beijing2006 & 0.22 & 0.74 & 1.00 \\
CLACE-6 & 0.22 & 0.69 & 1.00 \\
\hline Overall & 0.22 & 0.69 & 0.96 \\
\hline
\end{tabular}

median overestimation of $N_{\mathrm{CCN}}$ of $49,41,33,17$ and $2 \%$ for the $S_{\text {eff }}$ levels of $0.1,0.2,0.3,0.5$ and $1.0 \%$, respectively.

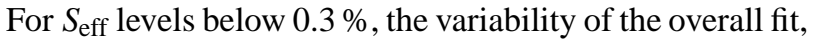
as shown by the prediction bounds, leads to the uncertainty of the predicted $N_{\mathrm{CCN}}$ of up to an average of $\sim 45 \%$. This uncertainty decreases exponentially for $S_{\text {eff }}$ levels above $0.3 \%$. A global modelling study conducted by Moore et al. (2013) reported that CDNC over the continental regions is fairly insensitive to $N_{\mathrm{CCN}}$, where a $4-71 \%$ uncertainty in $N_{\mathrm{CCN}}$ leads to a $1-23 \%$ uncertainty in CDNC. Since the overwhelming majority of measurements analysed in this paper were conducted on land, and the overall fit results in an uncertainty of the predicted annual mean $N_{\mathrm{CCN}}$ of up to $\sim 45 \%$, for many sites the use of the overall fit would yield a deviation of the predicted average CDNC of approximately less than $10 \%$. $\mathrm{CDNC}$, however, is more sensitive to $N_{\mathrm{CCN}}$ in cleaner regions with low total particle number concentrations, such as the Alaskan Arctic and remote oceans (Moore et al., 2013). In such areas the use of the overall fit may not be appropriate.

Four locations stand out in Fig. 4, which were not included in the overall fit. $A$ is visibly higher in Finokalia and during the COPS campaign than in other locations, with approximately $60 \%$ of the total aerosol population at both locations activating into cloud drops at the $S_{\text {eff }}$ of $\sim 0.4 \%$. Reasons for the observed behaviour in Finokalia were discussed in the preceding Sect. 3.1. During the COPS campaign the size distributions varied greatly, and, as will be shown later, Aitken mode aerosol was more hygroscopic than accumulation mode aerosol, possibly explaining the behaviour of the COPS activation curve seen in Fig. 4 at least for higher

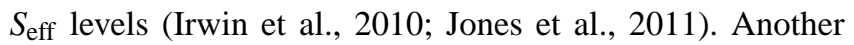
location with seemingly different activation curves is Pallas, where the activation spectrum changes throughout the year, and even at fairly high $S_{\text {eff }}$ level of $1.0 \%$, less than half of the total aerosol population activated into cloud drops. The long-term Jungfraujoch data set also exhibited comparatively low $A$ values, lower than those presented by Jurányi et al. (2011) and those during the CLACE-6 campaign at the same location (Fig. 4). While the $A$ values in the long-term Jungfraujoch data set were calculated with respect to CPC measurements of total particle number concentration, $A$ values for the CLACE- 6 campaign and those reported by Jurányi et al. (2011) were calculated with respect to integrated SMPS size distribution measurements with a higher size cutoff. While the aerosol hygroscopicity at these locations will be discussed later, the effect of the size distribution on the activation curves is evident.

The similarity in how $A$ responds to $S_{\text {eff }}$ at the majority of studied locations is an interesting result. In other words, at any given $S_{\text {eff }}$ the annual mean fraction of aerosol that will activate into cloud drops is pretty much the same in many locations, a fact that was pointed out previously by Andreae (2009). This phenomenon can easily be illustrated using the example of the activation curve during the RHaMBLe cruise in the tropical North Atlantic. As will be discussed later, while the $N_{\mathrm{CCN}}$ here is comparable to several other locations, the hygroscopicity of the aerosol is much higher, with the hygroscopicity parameter $\kappa$ being just below unity across all studied sizes. Yet, the fact that the aerosol is so hygroscopic seems to affect the activation efficiency of the aerosol in a similar manner as, for example, during the PRIDE-PRD2006 campaign in southeastern China. During this campaign absolute $N_{\mathrm{CCN}}$ was an order of magnitude higher than during the RHaMBLe cruise (Table 2), and the hygroscopicity was much lower (Rose et al., 2010). This order of magnitude difference in $N_{\mathrm{CCN}}$, a large difference in $\kappa$ and at least some presumed difference in the shape of size distribution between the RHaMBLe cruise and the PRIDE-PRD2006 campaign seem to result in no apparent difference in the fraction of the aerosol that activates into cloud drops at any given $S_{\text {eff. }}$. For most of the continental locations the overall fit presented in Table 4 can provide a reasonable estimation of annual mean $N_{\mathrm{CCN}}$ based on the $N_{\mathrm{CN}}$ for any given $S_{\text {eff. }}$. It should be kept in mind, however, that the activation curves in Fig. 4 for the long-term data sets do not reflect the potential short-term or seasonal variability, which, as can be seen in the example of the three Pallas campaigns, can be rather high. This and the fact that the short-term campaigns have been conducted during different seasons mean that the overall fit represents the annual mean activation behaviour and does not capture the variability on the shorter timescales.

One important uncertainty associated with the comparison of the activation curves in Fig. 4 is the precise size range from which $N_{\mathrm{CN}}$ is determined. In order for the activation curves to be directly comparable, the lower size limit of $N_{\mathrm{CN}}$ must 


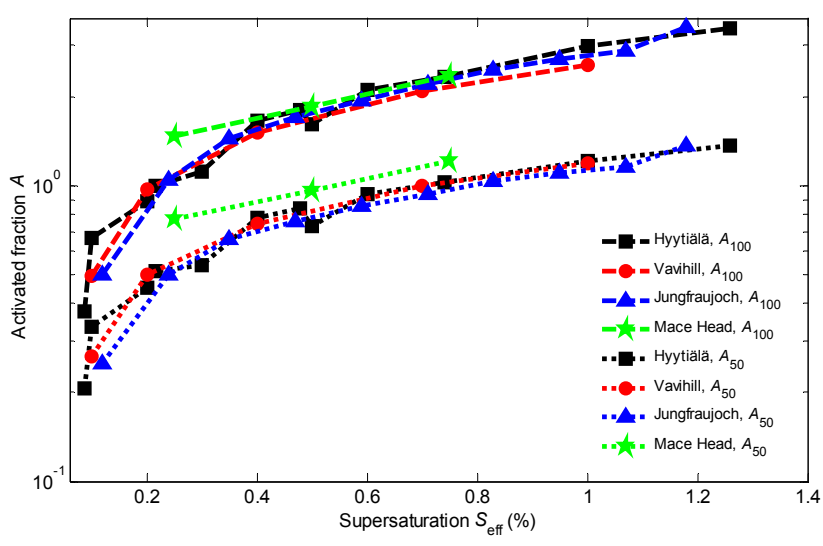

Figure 5. Average effective activated fractions $A_{100}\left(N_{\mathrm{CCN}} / N_{100}\right)$ and $A_{50}\left(N_{\mathrm{CCN}} / N_{50}\right)$ as a function of supersaturation $S_{\text {eff }}$ for the four long-term measurement locations.

be the same for all locations. In this study, data of the lower limit of $N_{\mathrm{CN}}$ for each location $\left(N_{\mathrm{CN}, D \min }\right)$ were unavailable and, hence, this parameter was likely to vary, complicating the comparison of activation curves in Fig. 4. To circumvent the problem, to conduct a more accurate comparison and to reveal more information about the effect of size distribution on CCN variability, $N_{100}$ and $N_{50}$ concentrations were used instead of $N_{\mathrm{CN}}$ to calculate the effective activated fractions corresponding to a certain lower cut-off diameter $A_{100}$ and $A_{50}$, respectively. These were calculated for the four longterm measurement locations only (where the data were available), and the results of the comparison are depicted in Fig. 5. When $N_{100}$ is used instead of $N_{\mathrm{CN}}$, the differences among locations described above almost disappear except for the lowest values of $S$. In general, the activation curve of $A_{100}$ for Mace Head is similar to those for Hyytiälä, Vavihill and Jungfraujoch for $S_{\text {eff }}$ above $0.4 \%$. In other words, when one considers the fraction of only accumulation mode particles that activates into cloud drops at any given $S_{\text {eff }}$, the difference in how $S_{\text {eff }}$ affects $A$ at all examined locations diminishes. In Hyytiälä, Vavihill and Jungfraujoch, particles with a dry diameter of $100 \mathrm{~nm}$ activate at the $S_{\text {eff }}$ of slightly higher than $0.2 \%$ assuming an internally mixed aerosol. Around this $S_{\text {eff }}$ Mace Head does exhibit a slightly higher $A_{100}$ compared to other locations, possibly due to the increased CCN activity of the organically enriched Aitken mode aerosol (Ovadnevaite et al., 2011).

When $A_{50}$ is examined in detail, the difference between Mace Head and other locations seen in Fig. 4 remains, with Mace Head exhibiting a higher activated fraction compared to the three other locations. In Hyytiälä, Vavihill and Jungfraujoch, particles with a dry diameter of $50 \mathrm{~nm}$ activate at a $S_{\text {eff }}$ of $\sim 0.7 \%$, while in Mace Head these same particles activate at a $S_{\text {eff }}$ of $\sim 0.55 \%$. Differences observed in Figs. 4 and 5 lead to the conclusion that $A_{50}$ and $A_{100}$ have a more stable dependence on $S$; i.e. the variability in the fraction of
nucleation/Aitken mode particles among different locations is large. Consequently, when comparing data sets of activated fractions $A$ from several locations with different expected concentrations of nucleation/Aitken mode particles and instrumental set-ups, a recommendation is made for the consideration of using $N_{100}$ and/or $N_{50}$ concentrations instead of $N_{\mathrm{CN}}$ when calculating $A$ coupled with $A$ values derived from total number concentrations. Besides more systematic comparison of activation curves and, therefore, more accurate results, such an approach can provide additional information about the effect of size distribution and its variability, and hygroscopicity on $\mathrm{CCN}$ activation. The use of $A_{100}$ and $A_{50}$ also diminishes the effect of the spatial variability of the fraction of nucleation/Aitken mode particles, those less relevant for CCN activation at typical ambient $S_{\text {eff levels. }}$

\subsection{CCN and their hygroscopicity}

Critical dry diameter $D_{\mathrm{c}}$ and hygroscopicity parameter $\kappa$ were provided for the majority of the presented locations, and the variation of $\kappa$ with dry size is seen in Fig. 6 (the figure is split into four panels for better visual representation). The variation of $\kappa$ with dry size is not the same everywhere, and three groups can be pointed out.

In the first group of locations $\kappa$ clearly increases with size; this is the case for Hyytiälä, Vavihill, Jungfraujoch (Fig. 6, upper left panel), Pallas (Fig. 6, upper right panel), and for the four campaigns conducted by the MPIC (Fig. 6, lower right panel). At these locations accumulation mode particles have a higher hygroscopicity than the Aitken mode particles, likely due to cloud processing. The results of the MannWhitney $U$ test (Mann and Whitney, 1947) for two populations that are not normally distributed (below and above $100 \mathrm{~nm}$ of dry size; Paramonov et al., 2013) reveal that in Hyytiälä, Vavihill, Jungfraujoch and Pallas A and C the difference in $\kappa$ is statistically significant at the $5 \%$ significance level; i.e. the median $\kappa$ of Aitken and accumulation mode particles are significantly different (Table 5). Published data for the PRIDE-PRD2006, CAREBeijing-2006, CLACE-6 and AMAZE-08 campaigns have previously reported such a trend (Rose et al., 2010, Gunthe et al., 2011, Rose et al., 2013 and Gunthe et al., 2009, respectively). Data for Chilbolton (Fig. 6, lower left panel) also reveal an increase in $\kappa$ with size, although absolute $\kappa$ values at this site may be underestimated due to the aerosol sample not being dried before entering the CCNC (Whitehead et al., 2014). Such behaviour of $\kappa$ leads to two implications. First, as already discussed in Su et al. (2010) and Paramonov et al. (2013), the hygroscopicity of the whole aerosol population can, and in some cases should, be presented as a function of size; this can be done by way of either separate $\kappa$ values for the Aitken and accumulation mode aerosol or hygroscopicity distribution functions. Values of $\kappa$ derived from the CCNC are frequently discussed in conjunction with the chemistry information obtained, e.g. from the aerosol mass spectrometer 


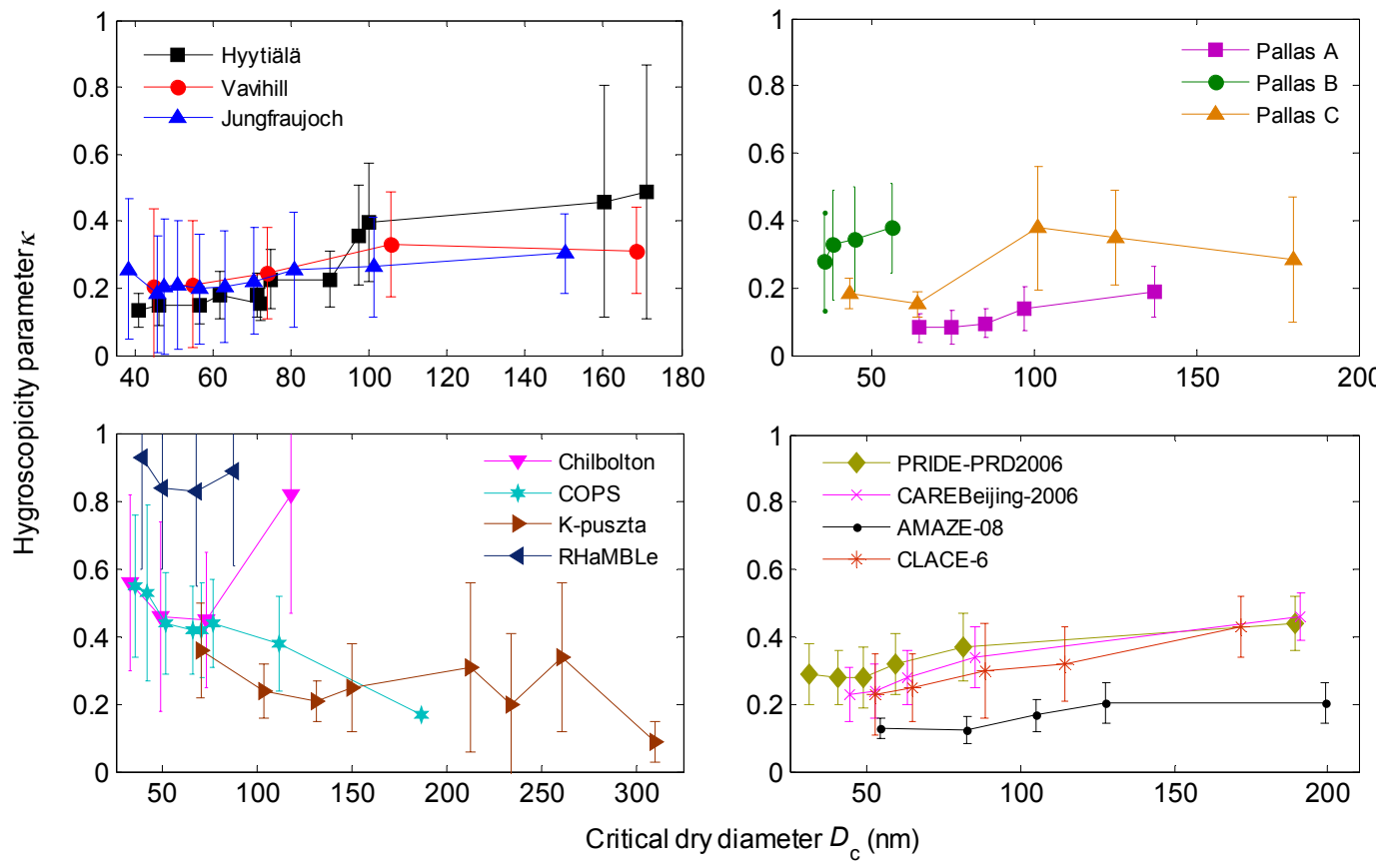

Figure 6. Mean hygroscopicity parameter $\kappa$ as a function of critical dry diameter $D_{\mathrm{c}}$ for selected locations. Figure split in four panels for more detail. Shown with one standard deviation.

Table 5. Median and percentile $\kappa$ values for Aitken $(<100 \mathrm{~nm})$ and accumulation $(>100 \mathrm{~nm})$ mode particles for Hyytiälä, Vavihill, Jungfraujoch and Pallas A and C.

\begin{tabular}{lccccccc}
\hline & \multicolumn{3}{c}{$<100 \mathrm{~nm}$} & & \multicolumn{3}{c}{$>100 \mathrm{~nm}$} \\
\cline { 2 - 3 } \cline { 6 - 7 } Station & median & 25th percentile & 75th percentile & & median & 25th percentile & 75th percentile \\
\hline Hyytiälä & 0.18 & 0.13 & 0.27 & & 0.29 & 0.22 & 0.45 \\
Vavihill & 0.20 & 0.15 & 0.28 & & 0.27 & 0.22 & 0.33 \\
Jungfraujoch & 0.18 & 0.12 & 0.28 & & 0.22 & 0.16 & 0.31 \\
Pallas A & 0.09 & 0.07 & 0.13 & & 0.13 & 0.09 & 0.20 \\
Pallas C & 0.18 & 0.15 & 0.27 & & 0.25 & 0.19 & 0.37 \\
\hline
\end{tabular}

(AMS) measurements. The second implication here is that if, due to instrumental limitations, such measurements are representative only of the accumulation mode particles, $\kappa$ values derived from such measurements should be extended to the Aitken mode particles with caution. The effect of extending the accumulation mode $\kappa$ down to the Aitken mode was examined using detailed data from Hyytiälä as an example. $N_{\mathrm{CCN}}$ was calculated using the median annual size distribution and $D_{\mathrm{c}}$ calculated with size-dependent and the assumed size-independent $\kappa$ values. It was found that if $\kappa$ of the accumulation mode is assumed to be the same for the Aitken mode, the $N_{\mathrm{CCN}}$, on average, is overestimated by 16 and $13.5 \%$ for the $S_{\text {eff }}$ of 0.6 and $1.0 \%$, respectively.

The second group of locations, or in this case only one location, exhibits a decrease of $\kappa$ with particle dry size, and such a trend exists only for the COPS campaign (Fig. 6, lower left panel). Apparently, at the mountainous site in the Black
Forest region of south-west Germany the chemical composition of the accumulation mode aerosol makes it less hygroscopic compared with the Aitken mode at supersaturated conditions (Irwin et al., 2010). However, the same study reported that the measurements by the hygroscopicity tandem DMA (HTDMA) in a sub-saturated regime revealed an increase of $\kappa$ with particle dry size.

The third group of locations, represented by the K-puszta station and RHaMBLe measurement campaign, is characterised by the absence of any dependence of $\kappa$ on the particle dry size. Though quite different in magnitude (Fig. 6, lower left panel), $\kappa$ values and, therefore, aerosol chemical composition seem to have no particular size dependence across the whole measured size range. Also of interest is the high aerosol hygroscopicity across the whole investigated aerosol size range (Aitken mode) during the RHaMBLe cruise - all $\kappa$ values are just below unity (Good et al., 2010). The marine 


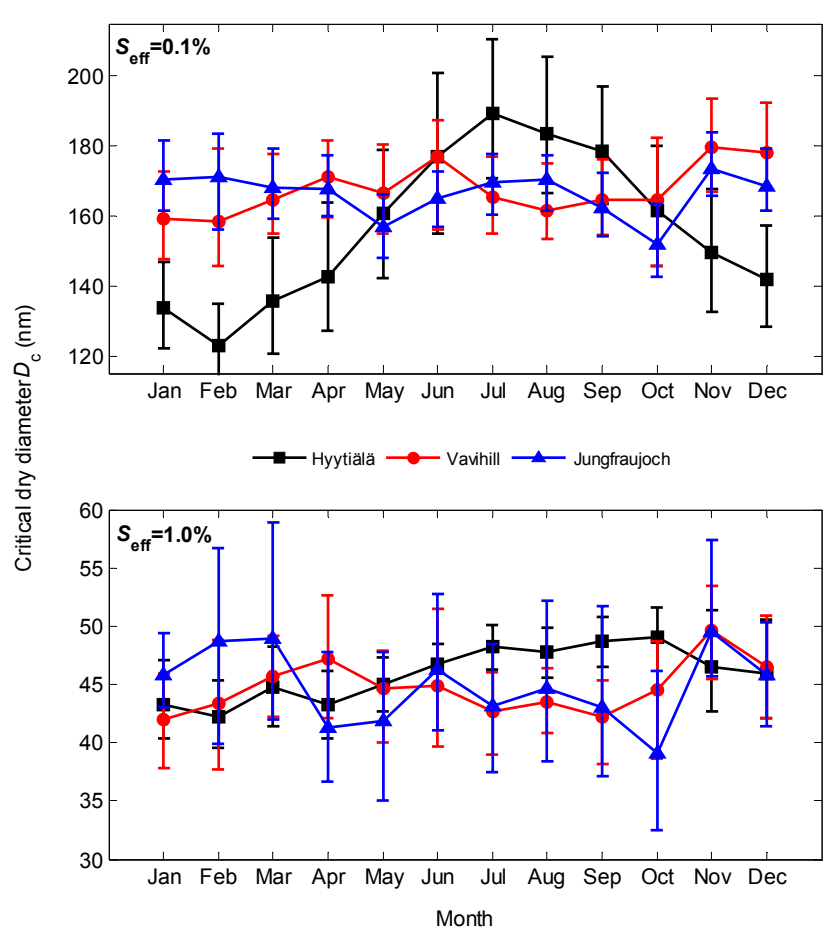

Figure 7. Monthly median $D_{\mathrm{c}}$ at the $S_{\text {eff }}$ of $0.1 \%$ (upper) and $1.0 \%$ (lower) for three long-term measurement locations. Error bars are 25th and 75th percentiles.

nature of the aerosol and clean background conditions of the remote tropical North Atlantic are likely responsible for high aerosol hygroscopicity.

Three of the four long-term data sets, excluding Mace Head, included $D_{\mathrm{c}}$ and $\kappa$ data, making it possible to examine aerosol hygroscopicity both on the annual basis and diurnal basis separated by seasons. Figure 7 presents the annual variation of $D_{\mathrm{c}}$ for lowest and highest $S_{\text {eff }}$ levels in Hyytiälä, Vavihill and Jungfraujoch. As can be seen in the $y$ axis of the upper panel, particles measured at the $S_{\text {eff }}$ of $0.1 \%$ are in the accumulation mode, i.e. $D_{\mathrm{c}}$ is larger than $100 \mathrm{~nm}$ in diameter. Of the three stations presented, $D_{\mathrm{c}}$ has an annual pattern only in Hyytiälä, with a minimum $D_{\mathrm{c}}$ and an increased hygroscopicity in the winter and a maximum $D_{\mathrm{c}}$ and a decreased hygroscopicity in the summer, as previously reported by Paramonov et al. (2013). The likely reason for a decrease in the accumulation mode particle hygroscopicity in Hyytiälä in the summer is the increase in the emissions of the volatile organic compounds (VOCs), leading to an increase in secondary organic aerosol (SOA) formation and, thus, a higher organic fraction. The higher hygroscopicity in the winter can also be explained by a higher sulphate fraction, stronger aerosol oxidation and potentially other ageing processes that are known to increase particle hygroscopicity (Furutani et al., 2008). No annual pattern is present in the aerosol hygroscopicity of accumulation mode aerosol in Vavihill and Jungfraujoch. The lower panel in Fig. 7 depicts

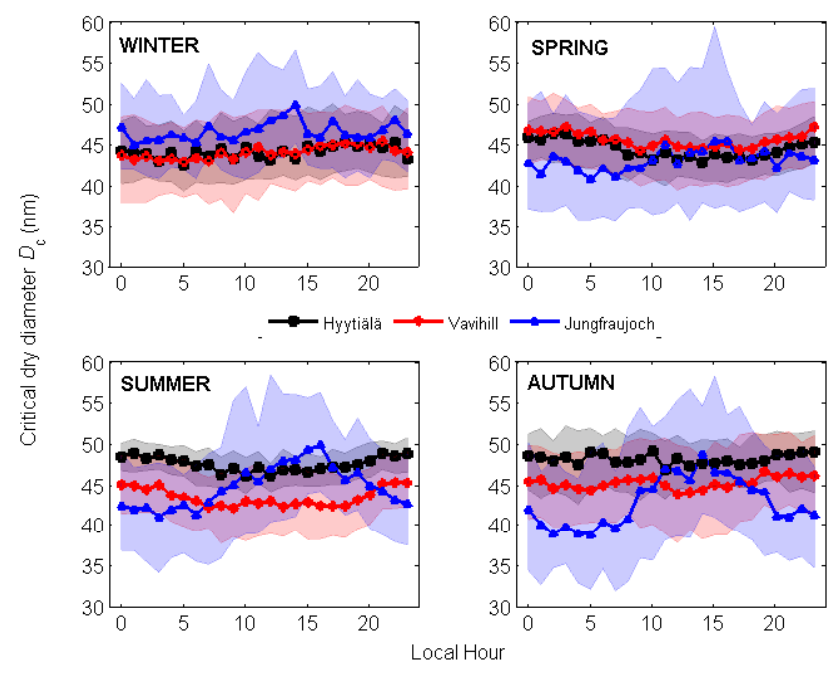

Figure 8. Hourly median critical dry diameters $D_{\mathrm{c}}$ at the $S_{\text {eff }}$ of $1.0 \%$ for three long-term measurement locations separated by seasons. Shaded areas represent the 25 th and 75 th percentiles, with colours corresponding to the median data series.

the annual variation of aerosol hygroscopicity for the Aitken mode aerosol, revealing no pattern for any of the three locations. The absence of a pattern coupled with the absence of an apparent difference among sites indicates that the aerosol hygroscopicity of Aitken, $\sim 50 \mathrm{~nm}$ aerosol is fairly similar and constant throughout the year at all three locations.

The diurnal patterns of aerosol hygroscopicity were analysed for Hyytiälä, Vavihill and Jungfraujoch on a seasonal basis. It was discovered that for the accumulation mode particles, those measured at the $S_{\text {eff }}$ of $0.1 \%$, no diurnal pattern was observed at any of the three locations in any of the seasons, indicating that throughout the day photochemistry does not have any apparent effect on the hygroscopicity of the accumulation mode particles. Diurnal patterns of aerosol hygroscopicity for Aitken mode particles can be seen in Fig. 8 . In the winter no particular pattern is visible at any of the locations; it can, however, be seen that while the aerosol hygroscopicity is similar between Hyytiälä and Vavihill, the Aitken mode aerosol at the Jungfraujoch is less hygroscopic. In the spring both Hyytiälä and Vavihill exhibit a clear diurnal pattern, which extends also into the summer. A peak in aerosol hygroscopicity is observed around midday when $D_{\mathrm{c}}$ reaches its minimum. Several previous studies have reported such behaviour in Hyytiälä and have attributed it to the vegetation activity, photochemistry and the ageing of organics during sunlight hours (Sihto et al., 2011; Cerully et al., 2011; Paramonov et al., 2013). While no diurnal pattern of aerosol hygroscopicity is visible for Jungfraujoch for winter and spring, a very clear pattern does exist in the summer and autumn. In these seasons Aitken mode particles exhibit an obvious decrease in hygroscopicity in the afternoon shown by the peak in $D_{\mathrm{c}}$ during these hours. This phenomenon has also been 
previously reported and attributed to the daytime intrusions of air from the planetary boundary layer (PBL) injecting less hygroscopic particles into the free troposphere (Kammermann et al., 2010a). The discussion above demonstrates that diurnal patterns of hygroscopicity are not the same everywhere and vary by seasons; however, the environments of Hyytiälä and Vavihill are similar enough to result in similar diurnal patterns.

\section{Conclusion}

CCNC measurement data from 14 locations, including four long-term measurement sites, have been analysed, compared and discussed with respect to the deduced $\mathrm{CCN}$ activation and hygroscopic properties. As already known, the pattern of how $N_{\mathrm{CCN}}$ and $A$ respond to the increasing $S$ is indicative of the total $N_{\mathrm{CN}}$ concentrations, the size distribution of the pre-existing aerosol population and its hygroscopicity. Certain marine locations exhibited high $A$ values and rapidly increasing $N_{\mathrm{CCN}}$ even at low $S$ values, as was the case during the COPS campaign in south-west Germany. At these locations aerosol populations are likely accumulation modedominated and/or of relatively high hygroscopicity. Pallas, a remote background location in northern Finland, exhibited a pattern of low $A$ values and slowly increasing $N_{\mathrm{CCN}}$ at low $S$ values, revealing the likelihood of Aitken mode-dominated aerosol and/or fairly low hygroscopicity at this site. Jungfraujoch, a high Alpine site in the free troposphere, also exhibited comparatively low $A$ values, as the particle number is often dominated by the Aitken mode particles. For the rest of the studied locations (the majority), the pattern of increasing $A$ with increasing $S$ was similar, i.e. at most locations the same fraction of aerosol activated into cloud drops at any given $S$. For example, $20 \%$ of the total aerosol population at most locations will activate into cloud drops at the $S$ of $0.1 \%$. A simple linear fit for estimating annual mean $N_{\mathrm{CCN}}$ at most continental locations is presented. When comparing activated fractions $A$ at several locations, a recommendation is made to use $N_{100}$ and/or $N_{50}$ when calculating $A$ values together with $A$ values derived from total number concentrations. Using this technique, a more accurate comparison should be performed for sites where the exact size range of $N_{\mathrm{CN}}$ is not known and where the concentrations of nucleation/Aitken mode particles are expected to be high, additionally revealing more information about the effect of size distribution and hygroscopicity on CCN activation.

The hygroscopicity of aerosol particles as a function of size is not the same at all locations; while $\kappa$ decreased with increasing size at a continental site in south-west Germany and was fluctuating without any particular size dependence across the observed size range in the remote tropical North Atlantic and rural central Hungary, all other locations exhibited an increase of $\kappa$ with size. In fact, at the rural background sites of southern Finland and southern Sweden, at a free tro- posphere site in the Swiss Alps and at a remote background site in northern Finland the difference in hygroscopicity between Aitken and accumulation mode aerosol was statistically significant at the $5 \%$ significance level. Therefore, assuming a size-independent $\kappa$ can lead to a substantial overestimation of $N_{\mathrm{CCN}}$ at higher levels of $S_{\text {eff }}$ (those above $0.6 \%$ ). The hygroscopicity of the whole aerosol population can be presented separately for Aitken and accumulation mode particles; additionally, hygroscopicity distribution functions can be used to analyse size-resolved CCNC data and efficiently describe the size dependence of $\kappa$ (Lance, 2007; Su et al., 2010; Jurányi et al., 2013). It is known, however, that in most cases the size distribution and its variation have a larger effect on the $N_{\mathrm{CCN}}$ than the particle hygroscopicity and its variation with size.

Among Hyytiälä, Vavihill and Jungfraujoch, no annual pattern of aerosol hygroscopicity was found for the Aitken mode aerosol. The accumulation mode aerosol exhibited a discernible annual pattern only in Hyytiälä, where a peak in hygroscopicity was found in February and a minimum in July. Such a pattern is likely attributed to the higher sulphate fraction and stronger aerosol oxidation in the winter and active SOA formation and higher organic fraction in the summer. Among the same three sites, no diurnal trend of aerosol hygroscopicity was found for accumulation mode aerosol. The hygroscopicity of the Aitken mode aerosol in Hyytiälä and Vavihill follows a clear diurnal pattern in the spring and summer - an increase in aerosol hygroscopicity was observed in the afternoon, likely due to the photochemistry and ageing of the organics. At the Jungfraujoch, Aitken mode aerosol showed a decrease in aerosol hygroscopicity in the afternoon during the summer and autumn; this phenomenon is caused by the injections from the planetary boundary layer containing somewhat less hygroscopic aerosol.

In general, the comparison of CCNC measurements is complicated by the variation of instrumental set-ups, settings, measurement times and intervals, performed calibrations, calculations and available parameters among sites. Supplementary data, such as aerosol size distribution and chemical composition, can enhance the uniformity of the analysis and expand the representativeness of the aforementioned results. However, as the first overview of its kind, the summary of CCNC measurements discussed here presents a unique insight into the $\mathrm{CCN}$ activation and hygroscopic properties in Europe and a few non-European sites. While, as shown here, CCNC measurements can provide useful information about the $\mathrm{CCN}$ and their activation into cloud droplets, the missing link in the aerosol-cloud interactions is the connection of CCN to the ambient CDNC. If filled, this gap can greatly improve our understanding of the processes and feedbacks within the aerosol-cloud-climate triangle and enhance the performance and accuracy of the global climate models. 
Acknowledgements. The research leading to the results published herein has received funding from the ACTRIS Project of the European Union Seventh Framework Programme (FP7/2007-2013) under grant agreement no. 262254. Additional funding was provided by the Max Planck Society. HEA-PRTLI4 Environment and Climate: Impact and Responses programme, EC 6th Framework programme project EUCAARI (036833-2), EC 7th Framework programme project BACCHUS (603445) are all acknowledged. The authors would like to thank Jakub Bialek for collecting CCN data and Ciaran Monahan for SMPS measurements at Mace Head station. The authors would also like to thank Tuomo Nieminen, Nønne L. Prisle and Ari Asmi for the help with statistics and data analysis. Simon Schallhart, Ksenia Atlaskina and Anna Nikandrova are all gratefully acknowledged for the discussions, help and support with the data analysis and plotting. The Centre of Excellence in Atmospheric Science - from molecular and biological processes to the global climate FCoE, cryosphere-atmosphere interactions in a changing Arctic climate CRAICC initiative, KONE foundation and the Swedish Research Council (VR) are acknowledged as well. The measurements at the Jungfraujoch were supported by MeteoSwiss in the framework of the Global Atmosphere Watch programme and the infrastructure was supported by the International Foundation High Altitude Research Station Jungfraujoch and Gornergrat. M. Gysel was supported by the ERC under grant 615922-BLACARAT.

Edited by: A. Petzold

\section{References}

Andreae, M. O.: Correlation between cloud condensation nuclei concentration and aerosol optical thickness in remote and polluted regions, Atmos. Chem. Phys., 9, 543-556, doi:10.5194/acp-9-543-2009, 2009.

Andreae, M. O. and Rosenfeld, D.: Aerosol-cloudprecipitation interactions. Part 1. The nature and sources of cloud-active aerosols, Earth-Sci. Rev., 89, 13-41, doi:10.1016/j.earscirev.2008.03.001, 2008.

Asmi, A., Wiedensohler, A., Laj, P., Fjaeraa, A.-M., Sellegri, K., Birmili, W., Weingartner, E., Baltensperger, U., Zdimal, V., Zikova, N., Putaud, J.-P., Marinoni, A., Tunved, P., Hansson, H.C., Fiebig, M., Kivekäs, N., Lihavainen, H., Asmi, E., Ulevicius, V., Aalto, P. P., Swietlicki, E., Kristensson, A., Mihalopoulos, N., Kalivitis, N., Kalapov, I., Kiss, G., de Leeuw, G., Henzing, B., Harrison, R. M., Beddows, D., O’Dowd, C., Jennings, S. G., Flentje, H., Weinhold, K., Meinhardt, F., Ries, L., and Kulmala, M.: Number size distributions and seasonality of submicron particles in Europe 2008-2009, Atmos. Chem. Phys., 11, 5505-5538, doi:10.5194/acp-11-5505-2011, 2011.

Beddows, D. C. S., Dall'Osto, M., Harrison, R. M., Kulmala, M., Asmi, A., Wiedensohler, A., Laj, P., Fjaeraa, A. M., Sellegri, K., Birmili, W., Bukowiecki, N., Weingartner, E., Baltensperger, U., Zdimal, V., Zikova, N., Putaud, J.-P., Marinoni, A., Tunved, P., Hansson, H.-C., Fiebig, M., Kivekäs, N., Swietlicki, E., Lihavainen, H., Asmi, E., Ulevicius, V., Aalto, P. P., Mihalopoulos, N., Kalivitis, N., Kalapov, I., Kiss, G., de Leeuw, G., Henzing, B., O’Dowd, C., Jennings, S. G., Flentje, H., Meinhardt, F., Ries, L., Denier van der Gon, H. A. C., and Visschedijk, A. J. H.:
Variations in tropospheric submicron particle size distributions across the European continent 2008-2009, Atmos. Chem. Phys., 14, 4327-4348, doi:10.5194/acp-14-4327-2014, 2014.

Bègue, N.: Evolution des propriétés physico-chimiques des aérosols désertiques issus de l'outflow africain, Ocean, Atmosphere, Université de la Réunion, Saint-Denis, Réunion, France, 2012.

Boucher, O. and Lohmann, U.: The sulfate-CCN-cloud albedo effect, Tellus, 47B, 281-300, 1995.

Boucher, O., Randall, D., Artaxo, P., Bretherton, C., Feingold, G., Forster, P., Kerminen, V.-M., Kondo, Y., Liao, H., Lohmann, U., Rasch, P., Satheesh, S. K., Sherwood, S., Stevens, B., and Zhang, X. Y.: Clouds and aerosols, in: Climate Change 2013: The Physical Science Basis, Contribution of Working Group I to the Fifth Assessment Report of the Intergovernmental Panel on Climate Change, edited by: Stocker, T. F., Qin, D., Plattner, G.-K., Tignor, M., Allen, S. K., Boschung, J., Nauels, A., Xia, Y., Bex, V., and Midgley, P. M., Cambridge University Press, Cambridge, UK and New York, NY, USA, 571-657, 2013.

Bougiatioti, A., Fountoukis, C., Kalivitis, N., Pandis, S. N., Nenes, A., and Mihalopoulos, N.: Cloud condensation nuclei measurements in the marine boundary layer of the Eastern Mediterranean: CCN closure and droplet growth kinetics, Atmos. Chem. Phys., 9, 7053-7066, doi:10.5194/acp-9-7053-2009, 2009.

Brus, D., Neitola, K., Asmi, E., Aurela, M., Makkonen, U., Svensson, J., Hyvärinen, A.-P., Hirsikkoa, A., Hakola, H., Hillamo, R., and Lihavainen, H.: Pallas cloud experiment, PACE 2012, AIP Conf. Proc., 1527, 964, doi:10.1063/1.4803433, 2013.

Campanelli, M., Estelles, V., Smyth, T., Tomasi, C., MartìnezLozano, M. P., Claxton, B., Muller, P., Pappalardo, G., Pietruczuk, A., Shanklin, J., Colwell, S., Wrench, C., Lupi, A., Mazzola, M., Lanconelli, C., Vitale, V., Congeduti, F., Dionisi, D., Cardillo, F., Cacciani, M., Casasanta, G., and Nakajima, T.: Monitoring of Eyjafjallajökull volcanic aerosol by the new European Skynet Radiometers (ESR) network, Atmos. Environ., 48, 33-45, 2012.

Carrico, M. C., Petters, M. D., Kreidenweis, S. M., Collett Jr., J. L., Engling, G., and Malm, W. C.: Aerosol hygroscopicity and cloud droplet activation of extracts of filters from biomass burning experiments, J. Geophys. Res., 113, D08206, doi:10.1029/2007JD009274, 2008.

Cerully, K. M., Raatikainen, T., Lance, S., Tkacik, D., Tiitta, P., Petäjä, T., Ehn, M., Kulmala, M., Worsnop, D. R., Laaksonen, A., Smith, J. N., and Nenes, A.: Aerosol hygroscopicity and CCN activation kinetics in a boreal forest environment during the 2007 EUCAARI campaign, Atmos. Chem. Phys., 11, 12369-12386, doi:10.5194/acp-11-12369-2011, 2011.

Chang, R. Y.-W., Liu, P. S. K., Leaitch, W. R., and Abbatt, J. P. D.: Comparison between measured and predicted CCN concentrations at Egbert, Ontario: Focus on the organic aerosol fraction at a semi-rural site, Atmos. Environ., 41, 8172-8182, 2007.

Chen, Y.-C., Christensen, M. W., Stephens, G. L., and Seinfeld, J. H.: Satellite-based estimate of global aerosol-cloud radiative forcing by marine warm clouds, Nat. Geosci., 7, 643-646, 2014. Collaud Coen, M., Weingartner, E., Furger, M., Nyeki, S., Prévôt, A. S. H., Steinbacher, M., and Baltensperger, U.: Aerosol climatology and planetary boundary influence at the Jungfraujoch analyzed by synoptic weather types, Atmos. Chem. Phys., 11, 5931-5944, doi:10.5194/acp-11-5931-2011, 2011. 
Covert, D. S., Gras, J. L., Wiedensohler, A., and Stratmann, F.: Comparison of directly measured $\mathrm{CCN}$ with $\mathrm{CCN}$ modeled from the number-size distribution in the marine boundary layer during ACE 1 at Cape Grim, Tasmania, J. Geophys. Res., 103, 1659716608, 1998.

Ditas, F., Shaw, R. A., Siebert, H., Simmel, M., Wehner, B., and Wiedensohler, A.: Aerosols-cloud microphysicsthermodynamics-turbulence: evaluating supersaturation in a marine stratocumulus cloud, Atmos. Chem. Phys., 12, 2459-2468, doi:10.5194/acp-12-2459-2012, 2012.

Dusek, U., Frank, G. P., Hildebrandt, L., Curtius, J., Schneider, J., Walter, S., Chand, D., Drewnick, F., Hings, S., Jung, D., Borrmann, S., and Andreae, M. O.: Size matters more than chemistry for cloud-nucleating ability of aerosol particles, Science, 312, 1375-1378, doi:10.1126/science.1125261, 2006.

Facchini, M. C., Decesari, S., Mircea, M., Fuzzi, S., and Loglio, G.: Surface tension of atmospheric wet aerosol and cloud/fog droplets in relation to their organic carbon content and chemical composition, Atmos. Environ., 34, 4853-4857, 2000.

Fors, E. O., Swietlicki, E., Svenningsson, B., Kristensson, A., Frank, G. P., and Sporre, M.: Hygroscopic properties of the ambient aerosol in southern Sweden - a two year study, Atmos. Chem. Phys., 11, 8343-8361, doi:10.5194/acp-11-8343-2011, 2011.

Furutani, H., Dall'osto, M., Roberts, G. C., and Prather, K. A.: Assessment of the relative importance of atmospheric aging on $\mathrm{CCN}$ activity derived from field observations, Atmos. Environ., 42, 3130-3142, 2008.

Garland, R. M., Schmid, O., Nowak, A., Achtert, P., Wiedensohler, A., Gunthe, S. S., Takegawa, N., Kita, K., Kondo, Y., Hu, M., Shao, M., Zeng, M., Zhu, T., Andreae, M. O., and Pöschl, U.: Aerosol optical properties observed during Campaign of Air Quality Research in Beijing 2006 (CAREBeijing-2006): Characteristic differences between the inflow and outflow of Beijing city air, J. Geophys. Res., 114, D00G04, doi:10.1029/2008JD010780, 2009.

Good, N., Topping, D. O., Allan, J. D., Flynn, M., Fuentes, E., Irwin, M., Williams, P. I., Coe, H., and McFiggans, G.: Consistency between parameterisations of aerosol hygroscopicity and CCN activity during the RHaMBLe discovery cruise, Atmos. Chem. Phys., 10, 3189-3203, doi:10.5194/acp-10-3189-2010, 2010.

Gunthe, S. S., King, S. M., Rose, D., Chen, Q., Roldin, P., Farmer, D. K., Jimenez, J. L., Artaxo, P., Andreae, M. O., Martin, S. T., and Pöschl, U.: Cloud condensation nuclei in pristine tropical rainforest air of Amazonia: size-resolved measurements and modeling of atmospheric aerosol composition and CCN activity, Atmos. Chem. Phys., 9, 7551-7575, doi:10.5194/acp-9-75512009, 2009.

Gunthe, S. S., Rose, D., Su, H., Garland, R. M., Achtert, P., Nowak, A., Wiedensohler, A., Kuwata, M., Takegawa, N., Kondo, Y., Hu, M., Shao, M., Zhu, T., Andreae, M. O., and Pöschl, U.: Cloud condensation nuclei $(\mathrm{CCN})$ from fresh and aged air pollution in the megacity region of Beijing, Atmos. Chem. Phys., 11, 1102311039, doi:10.5194/acp-11-11023-2011, 2011.

Hammer, E., Bukowiecki, N., Gysel, M., Jurányi, Z., Hoyle, C. R., Vogt, R., Baltensperger, U., and Weingartner, E.: Investigation of the effective peak supersaturation for liquid-phase clouds at the high-alpine site Jungfraujoch, Switzerland (3580 m a.s.l.),
Atmos. Chem. Phys., 14, 1123-1139, doi:10.5194/acp-14-11232014, 2014.

Hari, P. and Kulmala, M.: Station for Measuring EcosystemAtmosphere Relations (SMEAR II), Boreal Environ. Res., 10, 315-322, 2005.

Hatakka, J., Aalto, T., Aaltonen, V., Aurela, M., Hakola, H., Komppula, M,. Laurila, T., Lihavainen, H., Paatero, J., Salminen, K., and Viisanen, Y.: Overview of the atmospheric research activities and results at Pallas GAW station, Boreal Environ. Res., 8, 365-384, 2003.

Hitzenberger, R., Giebl, H., Petzold, A., Gysel, M., Nyeki, S., Weingartner, E., Baltensperger, U., and Wilson, C. W.: Properties of jet engine combustion particles during the PartEmis experiment. Hygroscopic growth at supersaturated conditions, Geophys. Res. Lett., 30, 1779, doi:10.1029/2003GL017294, 2003.

Hudson, J. G. and Noble, S.: CCN and vertical velocity influences on droplet concentrations and supersaturations in clean and polluted stratus clouds, J. Atmos. Sci., 71, 312-331, 2014.

Hudson, J. G., Hallett, J., and Rogers, C. F.: Field and laboratory measurements of cloud-forming properties of combustion aerosols, J. Geophys. Res., 96, 10847-10859, doi:10.1029/91JD00790, 1991.

Ion, A. C., Vermeylen, R., Kourtchev, I., Cafmeyer, J., Chi, X., Gelencsér, A., Maenhaut, W., and Claeys, M.: Polar organic compounds in rural $\mathrm{PM}_{2.5}$ aerosols from K-puszta, Hungary, during a 2003 summer field campaign: Sources and diel variations, Atmos. Chem. Phys., 5, 1805-1814, doi:10.5194/acp-5-1805-2005, 2005.

Irwin, M., Good, N., Crosier, J., Choularton, T. W., and McFiggans, G.: Reconciliation of measurements of hygroscopic growth and critical supersaturation of aerosol particles in central Germany, Atmos. Chem. Phys., 10, 11737-11752, doi:10.5194/acp10-11737-2010, 2010.

Jaatinen, A., Romakkaniemi, S., Anttila, T., Hyvärinen, A.-P., Hao, L.-Q., Kortelainen, A., Miettinen, P., Mikkonen, S., Smith, J. N., Virtanen, A., and Laaksonen, A.: The third Pallas Cloud Experiment: Consistency between the aerosol hygroscopic growth and CCN activity, Boreal Environ. Res., 19 (suppl. B), 368-382, 2014.

Jones, H. M., Crosier, J., Russell, A., Flynn, M. J., Irwin, M., Choularton, T. W., Coe, H., and McFiggans, G.: In situ aerosol measurements taken during the 2007 COPS field campaign at the Hornisgrinde ground site, Q. J. Roy. Meteorol. Soc., 137, 252266, 2011.

Jurányi, Z., Gysel, M., Weingartner, E., DeCarlo, P. F., Kammermann, L., and Baltensperger, U.: Measured and modelled cloud condensation nuclei number concentration at the high alpine site Jungfraujoch, Atmos. Chem. Phys., 10, 7891-7906, doi:10.5194/acp-10-7891-2010, 2010.

Jurányi, Z., Gysel, M., Weingartner, E., Bukowiecki, N., Kammermann, L., and Baltensperger, U.: A 17 month climatology of the cloud condensation nuclei number concentration at the high alpine site Jungfraujoch, J. Geophys. Res., 116, D10204, doi:10.1029/2010JD015199, 2011.

Jurányi, Z., Tritscher, T., Gysel, M., Laborde, M., Gomes, L., Roberts, G., Baltensperger, U., and Weingartner, E.: Hygroscopic mixing state of urban aerosol derived from sizeresolved cloud condensation nuclei measurements during the 
MEGAPOLI campaign in Paris, Atmos. Chem. Phys., 13, 64316446, doi:10.5194/acp-13-6431-2013, 2013.

Kammermann, L., Gysel, M., Weingartner, E., and Baltensperger, U.: 13-month climatology of the aerosol hygroscopicity at the free tropospheric site Jungfraujoch (3580 m a.s.1.), Atmos. Chem. Phys., 10, 10717-10732, doi:10.5194/acp-10-107172010, 2010a.

Kammermann, L., Gysel, M., Weingartner, E., Herich, H., Cziczo, D. J., Holst, T., Svenningsson, B., Arneth, A., and Baltensperger, U.: Subarctic atmospheric aerosol composition: 3. Measured and modeled properties of cloud condensation nuclei, J. Geophys. Res., 115, D04202, doi:10.1029/2009JD012447, 2010 b.

Kerminen, V.-M., Paramonov, M., Anttila, T., Riipinen, I., Fountoukis, C., Korhonen, H., Asmi, E., Laakso, L., Lihavainen, H., Swietlicki, E., Svenningsson, B., Asmi, A., Pandis, S. N., Kulmala, M., and Petäjä, T.: Cloud condensation nuclei production associated with atmospheric nucleation: a synthesis based on existing literature and new results, Atmos. Chem. Phys., 12, $12037-$ 12059, doi:10.5194/acp-12-12037-2012, 2012.

Khvorostyanov, V. I. and Curry, J. A.: Refinements to the Köhler's theory of aerosol equilibrium radii, size spectra, and droplet activation: Effects of humidity and insoluble fraction, J. Geophys. Res., 112, D05206, doi:10.1029/2006JD007672, 2007.

Knutson, E. O. and Whitby, K. T.: Aerosol classification by electric mobility: apparatus, theory and applications, J. Aerosol Sci., 6, 443-451, 1975

Köhler, H.: The nucleus in and the growth of hygroscopic droplets, T. Faraday Soc., 32, 1152-1161, 1936.

Komppula, M., Sihto, S.-L., Korhonen, H., Lihavainen, H., Kerminen, V.-M., Kulmala, M., and Viisanen, Y.: New particle formation in air mass transported between two measurement sites in Northern Finland, Atmos. Chem. Phys., 6, 2811-2824, doi:10.5194/acp-6-2811-2006, 2006.

Kuang, C., McMurry, P. H., and McCormick, A. V.: Determination of cloud condensation nuclei production from measured new particle formation events, Geophys. Res. Lett., 36, L09822, doi:10.1029/2009GL037584, 2009.

Kulmala, M., Korhonen, P., Vesala, T., Hansson, H.-C., Noone, K., and Svenningsson, B.: The effect of hygroscopicity on cloud droplet formation, Tellus B, 48, 347-360, 1996.

Kulmala, M., Asmi, A., Lappalainen, H. K., Baltensperger, U., Brenguier, J.-L., Facchini, M. C., Hansson, H.-C., Hov, Ø., O'Dowd, C. D., Pöschl, U., Wiedensohler, A., Boers, R., Boucher, O., de Leeuw, G., Denier van der Gon, H. A. C., Feichter, J., Krejci, R., Laj, P., Lihavainen, H., Lohmann, U., McFiggans, G., Mentel, T., Pilinis, C., Riipinen, I., Schulz, M., Stohl, A., Swietlicki, E., Vignati, E., Alves, C., Amann, M., Ammann, M., Arabas, S., Artaxo, P., Baars, H., Beddows, D. C. S., Bergström, R., Beukes, J. P., Bilde, M., Burkhart, J. F., Canonaco, F., Clegg, S. L., Coe, H., Crumeyrolle, S., D'Anna, B., Decesari, S., Gilardoni, S., Fischer, M., Fjaeraa, A. M., Fountoukis, C., George, C., Gomes, L., Halloran, P., Hamburger, T., Harrison, R. M., Herrmann, H., Hoffmann, T., Hoose, C., Hu, M., Hyvärinen, A., Hõrrak, U., Iinuma, Y., Iversen, T., Josipovic, M., Kanakidou, M., Kiendler-Scharr, A., Kirkevåg, A., Kiss, G., Klimont, Z., Kolmonen, P., Komppula, M., Kristjánsson, J.-E., Laakso, L., Laaksonen, A., Labonnote, L., Lanz, V. A., Lehtinen, K. E. J., Rizzo, L. V., Makkonen, R., Manninen, H. E., McMeeking, G., Merikanto, J., Minikin, A., Mirme, S., Morgan, W. T.,
Nemitz, E., O’Donnell, D., Panwar, T. S., Pawlowska, H., Petzold, A., Pienaar, J. J., Pio, C., Plass-Duelmer, C., Prévôt, A. S. H., Pryor, S., Reddington, C. L., Roberts, G., Rosenfeld, D., Schwarz, J., Seland, Ø., Sellegri, K., Shen, X. J., Shiraiwa, M., Siebert, H., Sierau, B., Simpson, D., Sun, J. Y., Topping, D., Tunved, P., Vaattovaara, P., Vakkari, V., Veefkind, J. P., Visschedijk, A., Vuollekoski, H., Vuolo, R., Wehner, B., Wildt, J., Woodward, S., Worsnop, D. R., van Zadelhoff, G.-J., Zardini, A. A., Zhang, K., van Zyl, P. G., Kerminen, V.-M., Carslaw, K., and Pandis, S. N.: General overview: European Integrated project on Aerosol Cloud Climate and Air Quality interactions (EUCAARI) - integrating aerosol research from nano to global scales, Atmos. Chem. Phys., 11, 13061-13143, doi:10.5194/acp11-13061-2011, 2011.

Laaksonen, A., Hamed, A., Joutsensaari, J., Hiltunen, L., Cavalli, F., Junkermann, W., Asmi, A., Fuzzi, S., and Facchini, M. C.: Cloud condensation nucleus production from nucleation events at a highly polluted region, Geophys. Res. Lett., 32, L06812, doi:10.1029/2004GL022092, 2005

Lance, S.: Quantifying compositional impacts of ambient aerosol on cloud droplet formation, $\mathrm{PhD}$ thesis, Georgia Institute of Technology, Atlanta GA, USA, 166 p., 2007.

Levin, E. J. T., Prenni, A. J., Palm, B. B., Day, D. A., CampuzanoJost, P., Winkler, P. M., Kreidenweis, S. M., DeMott, P. J., Jimenez, J. L., and Smith, J. N.: Size-resolved aerosol composition and its link to hygroscopicity at a forested site in Colorado, Atmos. Chem. Phys., 14, 2657-2667, doi:10.5194/acp-14-26572014, 2014.

Mann, H. B. and Whitney, D. R.: On a test of whether one of two random variables is stochastically larger than the other, Ann Math. Stat., 18, 50-60, 1947.

Martin, S. T., Andreae, M. O., Althausen, D., Artaxo, P., Baars, H., Borrmann, S., Chen, Q., Farmer, D. K., Guenther, A., Gunthe, S. S., Jimenez, J. L., Karl, T., Longo, K., Manzi, A., Müller, T., Pauliquevis, T., Petters, M. D., Prenni, A. J., Pöschl, U., Rizzo, L. V., Schneider, J., Smith, J. N., Swietlicki, E., Tota, J., Wang, J., Wiedensohler, A., and Zorn, S. R.: An overview of the Amazonian Aerosol Characterization Experiment 2008 (AMAZE08), Atmos. Chem. Phys., 10, 11415-11438, doi:10.5194/acp10-11415-2010, 2010.

Mason, B. J. and Chien, C. W.: Cloud-droplet growth by condensation in cumulus, Q. J. Roy. Meteorol. Soc., 88, 136-142, 1962.

McFiggans, G., Artaxo, P., Baltensperger, U., Coe, H., Facchini, M. C., Feingold, G., Fuzzi, S., Gysel, M., Laaksonen, A., Lohmann, U., Mentel, T. F., Murphy, D. M., O’Dowd, C. D., Snider, J. R., and Weingartner, E.: The effect of physical and chemical aerosol properties on warm cloud droplet activation, Atmos. Chem. Phys., 6, 2593-2649, doi:10.5194/acp-6-2593-2006, 2006.

Mensah, A. A., Holzinger, R., Otjes, R., Trimborn, A., Mentel, Th. F., ten Brink, H., Henzing, B., and Kiendler-Scharr, A.: Aerosol chemical composition at Cabauw, The Netherlands as observed in two intensive periods in May 2008 and March 2009, Atmos. Chem. Phys., 12, 4723-4742, doi:10.5194/acp-12-4723-2012, 2012.

Moore, R. H., Karydis, V. A., Capps, S. L., Lathem, T. L., and Nenes, A.: Droplet number uncertainties associated with $\mathrm{CCN}$ : an assessment using observations and a global model adjoint, Atmos. Chem. Phys., 13, 4235-4251, doi:10.5194/acp-13-42352013, 2013. 
Morales Betancourt, R. and Nenes, A.: Understanding the contributions of aerosol properties and parameterization discrepancies to droplet number variability in a global climate model, Atmos. Chem. Phys., 14, 4809-4826, doi:10.5194/acp-14-48092014, 2014.

O’Dowd, C., Ceburnis, D., Ovadnevaite, J., Vaishya, A., Rinaldi, M., and Facchini, M. C.: Do anthropogenic, continental or coastal aerosol sources impact on a marine aerosol signature at Mace Head?, Atmos. Chem. Phys., 14, 10687-10704, doi:10.5194/acp-14-10687-2014, 2014.

Ovadnevaite, J., Ceburnis, D., Martucci, G., Bialek, J., Monahan, C., Rinaldi, M., Facchini, M. C., Berresheim, H., Worsnop, D. R., and O'Dowd, C.: Primary marine organic aerosol: A dichotomy of low hygroscopicity and high CCN activity, Geophys. Res. Lett., 38, L21806, doi:10.1029/2011GL048869, 2011.

Pandis, S. N., Russell, L. M., and Seinfeld, J. H.: The relationship between DMS flux and CCN concentration in remote marine regions, J. Geophys. Res., 99, 16945-16957, 1994.

Paramonov, M., Aalto, P. P., Asmi, A., Prisle, N., Kerminen, V.M., Kulmala, M., and Petäjä, T.: The analysis of size-segregated cloud condensation nuclei counter (CCNC) data and its implications for cloud droplet activation, Atmos. Chem. Phys., 13, 10285-10301, doi:10.5194/acp-13-10285-2013, 2013.

Perry, K. D., Cliff, S. S., and Jimenez-Cruz, M. P.: Evidence for hygroscopic mineral dust particles from the Intercontinental Transport and Chemical Transformation Experiment, J. Geophys. Res., 109, D23S28, doi:10.1029/2004JD004979, 2004.

Petters, M. D. and Kreidenweis, S. M.: A single parameter representation of hygroscopic growth and cloud condensation nucleus activity, Atmos. Chem. Phys., 7, 1961-1971, doi:10.5194/acp-71961-2007, 2007.

Quinn, P. K., Bates, T. S., Coffman, D. J., and Covert, D. S.: Influence of particle size and chemistry on the cloud nucleating properties of aerosols, Atmos. Chem. Phys., 8, 1029-1042, doi:10.5194/acp-8-1029-2008, 2008.

Ramanathan, V., Crutzen, P. J., Kiehl, J. T., and Rosenfeld, D.: Aerosols, climate, and the hydrological cycle, Science, 294, 2119-2124, 2001.

Rissler, J., Pagels, J., Swietlicki, E., Wierzbicka, A., Strand, M., Lillieblad, L., Sanati, M., and Bohgard, M.: Hygroscopic behavior of aerosol particles emitted from biomass fired grate boilers, Aerosol. Sci. Tech., 39, 919-930, doi:10.1080/02786820500331068, 2005.

Roberts, G. C. and Nenes, A.: A continuous-flow streamwise thermal-gradient $\mathrm{CCN}$ chamber for atmospheric measurements, Aerosol Sci. Tech., 39, 206-221, doi:10.1080/027868290913988, 2005.

Rose, D., Gunthe, S. S., Mikhailov, E., Frank, G. P., Dusek, U., Andreae, M. O., and Pöschl, U.: Calibration and measurement uncertainties of a continuous-flow cloud condensation nuclei counter (DMT-CCNC): CCN activation of ammonium sulfate and sodium chloride aerosol particles in theory and experiment, Atmos. Chem. Phys., 8, 1153-1179, doi:10.5194/acp-8-11532008, 2008.

Rose, D., Nowak, A., Achtert, P., Wiedensohler, A., Hu, M., Shao, M., Zhang, Y., Andreae, M. O., and Pöschl, U.: Cloud condensation nuclei in polluted air and biomass burning smoke near the mega-city Guangzhou, China - Part 1: Size-resolved measurements and implications for the modeling of aerosol particle hy- groscopicity and CCN activity, Atmos. Chem. Phys., 10, 33653383, doi:10.5194/acp-10-3365-2010, 2010.

Rose, D., Gunthe, S. S., Su, H., Garland, R. M., Yang, H., Berghof, M., Cheng, Y. F., Wehner, B., Achtert, P., Nowak, A., Wiedensohler, A., Takegawa, N., Kondo, Y., Hu, M., Zhang, Y., Andreae, M. O., and Pöschl, U.: Cloud condensation nuclei in polluted air and biomass burning smoke near the mega-city Guangzhou, China - Part 2: Size-resolved aerosol chemical composition, diurnal cycles, and externally mixed weakly $\mathrm{CCN}$-active soot particles, Atmos. Chem. Phys., 11, 2817-2836, doi:10.5194/acp-112817-2011, 2011.

Rose, D., Gunthe, S. S., Jurányi, Z., Gysel, M., Frank, G. P., Schneider, J., Curtius, J., and Pöschl, U.: Size-resolved and integral measurements of cloud condensation nuclei $(\mathrm{CCN})$ at the high-alpine site Jungfraujoch, Atmos. Chem. Phys. Discuss., 13, 32575-32624, doi:10.5194/acpd-13-32575-2013, 2013.

Rosenfeld, D., Sherwood, S., Wood, R., and Donner, L.: Climate effects of aerosol-cloud interactions, Science, 343, 379-380, 2014.

Sihto, S.-L., Mikkilä, J., Vanhanen, J., Ehn, M., Liao, L., Lehtipalo, K., Aalto, P. P., Duplissy, J., Petäjä, T., Kerminen, V.-M., Boy, M., and Kulmala, M.: Seasonal variation of CCN concentrations and aerosol activation properties in boreal forest, Atmos. Chem. Phys., 11, 13269-13285, doi:10.5194/acp-11-13269-2011, 2011.

Snider, J. R. and Brenguier, J.-L.: Cloud condensation nuclei and cloud droplet measurements during ACE-2, Tellus, 52B, 828842, 2000.

Sogacheva, L., Dal Maso, M., Kerminen, V.-M., and Kulmala, M.: Probability of nucleation events and aerosol particle concentration in different air mass types arriving at Hyytiälä, southern Finland, based on back trajectories analysis, Boreal Environ. Res., 10, 479-491, 2005.

Stock, M., Cheng, Y. F., Birmili, W., Massling, A., Wehner, B., Müller, T., Leinert, S., Kalivitis, N., Mihalopoulos, N., and Wiedensohler, A.: Hygroscopic properties of atmospheric aerosol particles over the Eastern Mediterranean: implications for regional direct radiative forcing under clean and polluted conditions, Atmos. Chem. Phys., 11, 4251-4271, doi:10.5194/acp11-4251-2011, 2011.

Su, H., Rose, D., Cheng, Y. F., Gunthe, S. S., Massling, A., Stock, M., Wiedensohler, A., Andreae, M. O., and Pöschl, U.: Hygroscopicity distribution concept for measurement data analysis and modeling of aerosol particle mixing state with regard to hygroscopic growth and CCN activation, Atmos. Chem. Phys., 10, 7489-7503, doi:10.5194/acp-10-7489-2010, 2010.

Svenningsson, I. B., Hansson, H. C., Wiedensohler, A., Ogren, J. A., Noone, K. J., and Hallberg, A.: Hygroscopic growth of aerosol-particles in the Po Valley, Tellus B, 44, 556-569, doi:10.1034/j.1600-0889.1992.t01-1-00009.x, 1992.

Topping, D. O.: Modelling the hygroscopic properties of atmospheric aerosols, $\mathrm{PhD}$ thesis, The University of Manchester, Manchester, UK, 257 p., 2005.

Tunved, P., Hansson, H.-C., Kulmala, M., Aalto, P., Viisanen, Y., Karlsson, H., Kristensson, A., Swietlicki, E., Dal Maso, M., Ström, J., and Komppula, M.: One year boundary layer aerosol size distribution data from five nordic background stations, Atmos. Chem. Phys., 3, 2183-2205, doi:10.5194/acp-3-2183-2003, 2003. 
Twomey, S.: The nuclei of natural cloud formation part II: The supersaturation in natural clouds and the variation of cloud droplet concentration, Geofisica pura e applicata, 43, 243-249, 1959.

Vaillancourt, P. A., Yau, M. K., and Bartello, P.: Microscopic approach to cloud droplet growth by condensation. Part II: Turbulence, clustering, and condensational growth, J. Atmos. Sci., 59, 3421-3435, 2002.

Wang, J., Cubison, M. J., Aiken, A. C., Jimenez, J. L., and Collins, D. R.: The importance of aerosol mixing state and size-resolved composition on $\mathrm{CCN}$ concentration and the variation of the importance with atmospheric aging of aerosols, Atmos. Chem. Phys., 10, 7267-7283, doi:10.5194/acp-10-7267-2010, 2010.

Wang, S. and Flagan, R.: Scanning electrical mobility spectrometer, J. Aerosol Sci., 20, 1485-1488, 1989.

Weingartner, E., Burtscher, H., and Baltensperger, U.: Hygroscopic properties of carbon and diesel soot particles, Atmos. Environ., 31, 2311-2327, doi:10.1016/S1352-2310(97)00023-X, 1997.

Wex, H., Hennig, T., Salma, I., Ocskay, R., Kiselev, A., Henning, S., Massling, A., Wiedensohler, A., and Stratmann, F.: Hygroscopic growth and measured and modeled critical super-saturations of an atmospheric HULIS sample, Geophys. Res. Lett., 34, L02818, doi:10.1029/2006GL028260, 2007.

Whitehead, J. D., Irwin, M., Allan, J. D., Good, N., and McFiggans, G.: A meta-analysis of particle water uptake reconciliation studies, Atmos. Chem. Phys., 14, 11833-11841, doi:10.5194/acp-1411833-2014, 2014
Wiedensohler, A., Birmili, W., Nowak, A., Sonntag, A., Weinhold, K., Merkel, M., Wehner, B., Tuch, T., Pfeifer, S., Fiebig, M., Fjäraa, A. M., Asmi, E., Sellegri, K., Depuy, R., Venzac, H., Villani, P., Laj, P., Aalto, P., Ogren, J. A., Swietlicki, E., Williams, P., Roldin, P., Quincey, P., Hüglin, C., Fierz-Schmidhauser, R., Gysel, M., Weingartner, E., Riccobono, F., Santos, S., Grüning, C., Faloon, K., Beddows, D., Harrison, R., Monahan, C., Jennings, S. G., O’Dowd, C. D., Marinoni, A., Horn, H.-G., Keck, L., Jiang, J., Scheckman, J., McMurry, P. H., Deng, Z., Zhao, C. S., Moerman, M., Henzing, B., de Leeuw, G., Löschau, G., and Bastian, S.: Mobility particle size spectrometers: harmonization of technical standards and data structure to facilitate high quality long-term observations of atmospheric particle number size distributions, Atmos. Meas. Tech., 5, 657-685, doi:10.5194/amt5-657-2012, 2012.

Wittbom, C., Eriksson, A. C., Rissler, J., Carlsson, J. E., Roldin, P., Nordin, E. Z., Nilsson, P. T., Swietlicki, E., Pagels, J. H., and Svenningsson, B.: Cloud droplet activity changes of soot aerosol upon smog chamber ageing, Atmos. Chem. Phys., 14, 9831-9854, doi:10.5194/acp-14-9831-2014, 2014. 